Article

\title{
Geochronological and Geochemical Constraints on the Origin of the Hutouya Polymetallic Skarn Deposit in the East Kunlun Orogenic Belt, NW China
}

\author{
Hongchang Gao ${ }^{1}$, Fengyue Sun ${ }^{1,2, *}$, Bile $\mathrm{Li}^{1}$, Ye Qian ${ }^{1,2}$, Li Wang ${ }^{1}$ and Yajing Zhang ${ }^{1}$ \\ 1 College of Earth Sciences, Jilin University, Changchun 130061, China; gaohc14@mails.jlu.edu.cn (H.G.); \\ libl@jlu.edu.cn (B.L.); qianye@jlu.edu.cn (Y.Q.); wang_1@jlu.edu.cn (L.W.); yjzhang1985@jlu.edu.cn (Y.Z.) \\ 2 Key Laboratory of Mineral Resources Evaluation in Northeast Asia, Ministry of Nature Resources of China, \\ Changchun 130061, China \\ * Correspondence: sfy@jlu.edu.cn; Tel./Fax: +86-0431-8850-2055
}

Received: 27 October 2020; Accepted: 14 December 2020; Published: 18 December 2020

check for updates

\begin{abstract}
The Hutouya polymetallic skarn deposit lies in the Qimantagh area of the East Kunlun Orogenic Belt, NW China. Skarnization and mineralization at the deposit are closely associated with contemporary felsic intrusions. In this paper, zircon $\mathrm{U}-\mathrm{Pb}$ ages and zircon $\mathrm{Hf}$ isotope as well as whole-rock geochemical and whole-rock Sr-Nd isotope data are reported for intrusive rocks and crystal tuff of the Elashan Formation in the Hutouya area. Moreover, Re-Os ages and S-Pb isotopes are also reported for the ore minerals in the Hutouya deposit. The Zircon laser ablation-inductively coupled plasma-mass spectrometry (LA-ICP-MS) U-Pb age of granodiorite and Re-Os isochron age of molybdenite suggest that mineralizations occurred at ca. $227 \mathrm{Ma}$ and that the granodiorite and molybdenite are closely related petrogenetically. All the granitoids in the Hutouya deposit are high-K calc-alkaline and metaluminous to weakly peraluminous I-type granitoids. Among them, the ore-forming granitoids were derived by the mixing of crust-derived (either juvenile or ancient mature lower crust) and mantle-derived magmas, whereas the non-ore-related granite porphyry was generated by the partial melting of a single ancient mature lower crust. The magmas of all the granitoids underwent extensive fractionation-crystallization during the process of rising and emplacement. The sulfur of the analyzed samples from the northern and middle zone of Hutouya deposit (including No. II, III, IV, and VI ore belts) belongs to deep magmatic sulfur, while the sulfur of samples from the southern zone of Hutouya deposit (No. VII ore belt) includes not only deep magmatic sulfur but also a contribution of strata sulfur. All the ore mineral samples in the Hutouya deposit have similar $\mathrm{Pb}$ compositions that are consistently derived from a mixed source of upper crust and mantle. Tectonic discrimination diagrams indicate a post-collisional setting for all granitic rocks of the Hutouya skarn deposit, which is therefore considered a product of a the post-collision extensional system and is consistent with other porphyry-skarn deposits within the East Kunlun Orogenic Belt.
\end{abstract}

Keywords: zircon U-Pb age; molybdenite Re-Os age; geochemistry; post-collision; Hutouya deposit; East Kunlun

\section{Introduction}

The East Kunlun Orogenic Belt (EKOB; Figure 1a,b) is one of the most significant polymetallic belts in China [1], with many studies of its numerous porphyry- and skarn-type deposits having been undertaken in recent years (Table 1). In particular, the Qimantagh area (Figure 1b,c), located in the northern $\mathrm{EKOB}$, is the top priority of researchers for skarn and porphyry-type $\mathrm{Fe}-\mathrm{Cu}-\mathrm{Pb}-\mathrm{Zn}-\mathrm{Mo}-\mathrm{W}-\mathrm{Sn}$ deposits, including the Galinge Fe skarn deposit [2], Tawenchahan skarn Fe-Cu-Zn deposit [3], 
Yemaquan skarn Fe-Cu-Pb-Zn deposit [4,5], Hutouya skarn Fe-Cu-Pb-Zn deposit [6], and Yazigou porphyry Cu-Mo deposit [7,8].
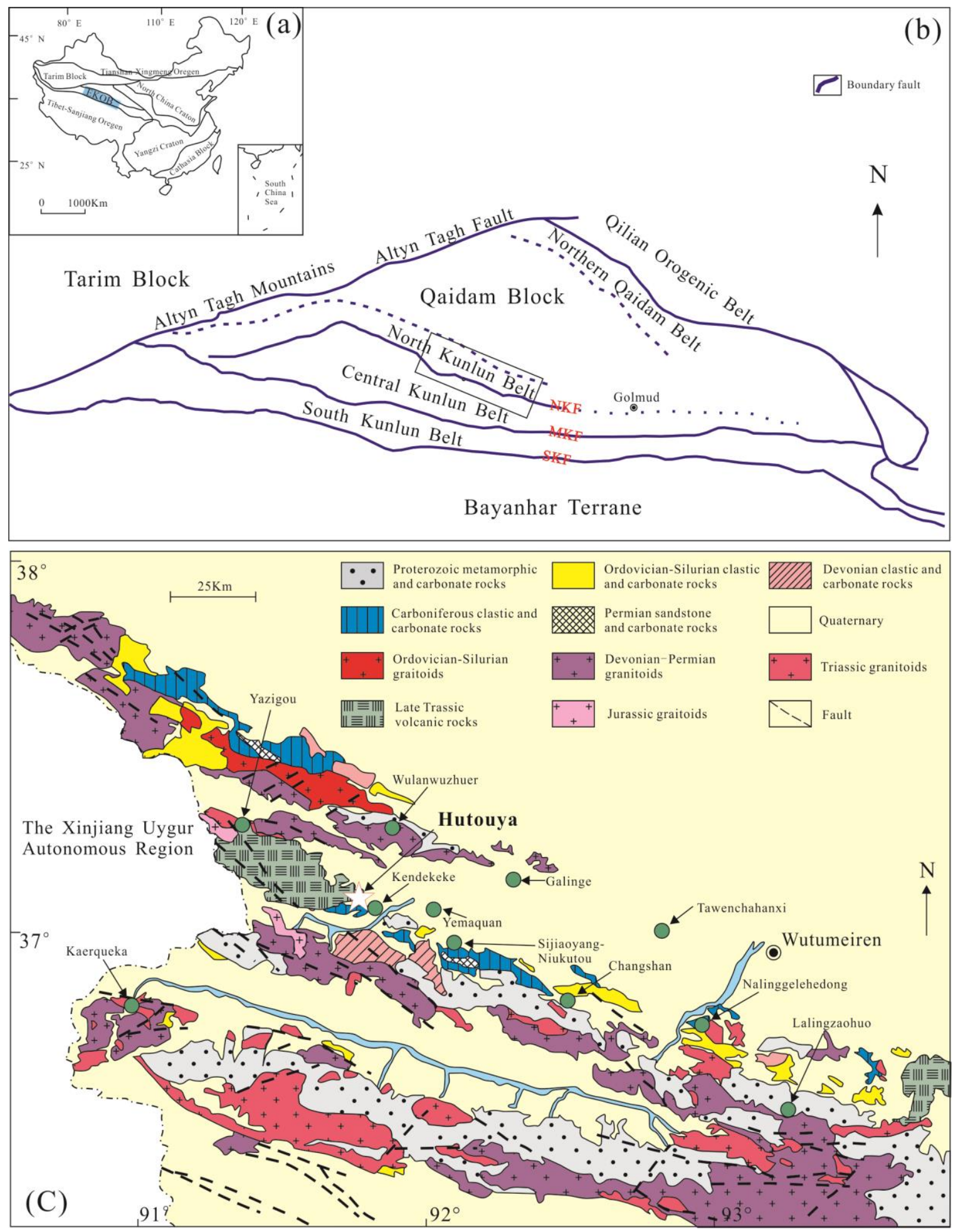

Figure 1. (a) Tectonic map of China showing the location of the East Kunlun Orogen Belt (EKOB). (b) Tectonic map of the EKOB (modified after [9]; the square frame represents the location of Qimantag area). (c) Geological map showing the main mineral deposit types in the Qimantag area (modified after [10]). 
Table 1. Magmatic and mineralization ages for porphyry-skarn polymetallic deposits of the East Kunlun area. LA-ICP-MS: laser ablation-inductively coupled plasma-mass spectrometry.

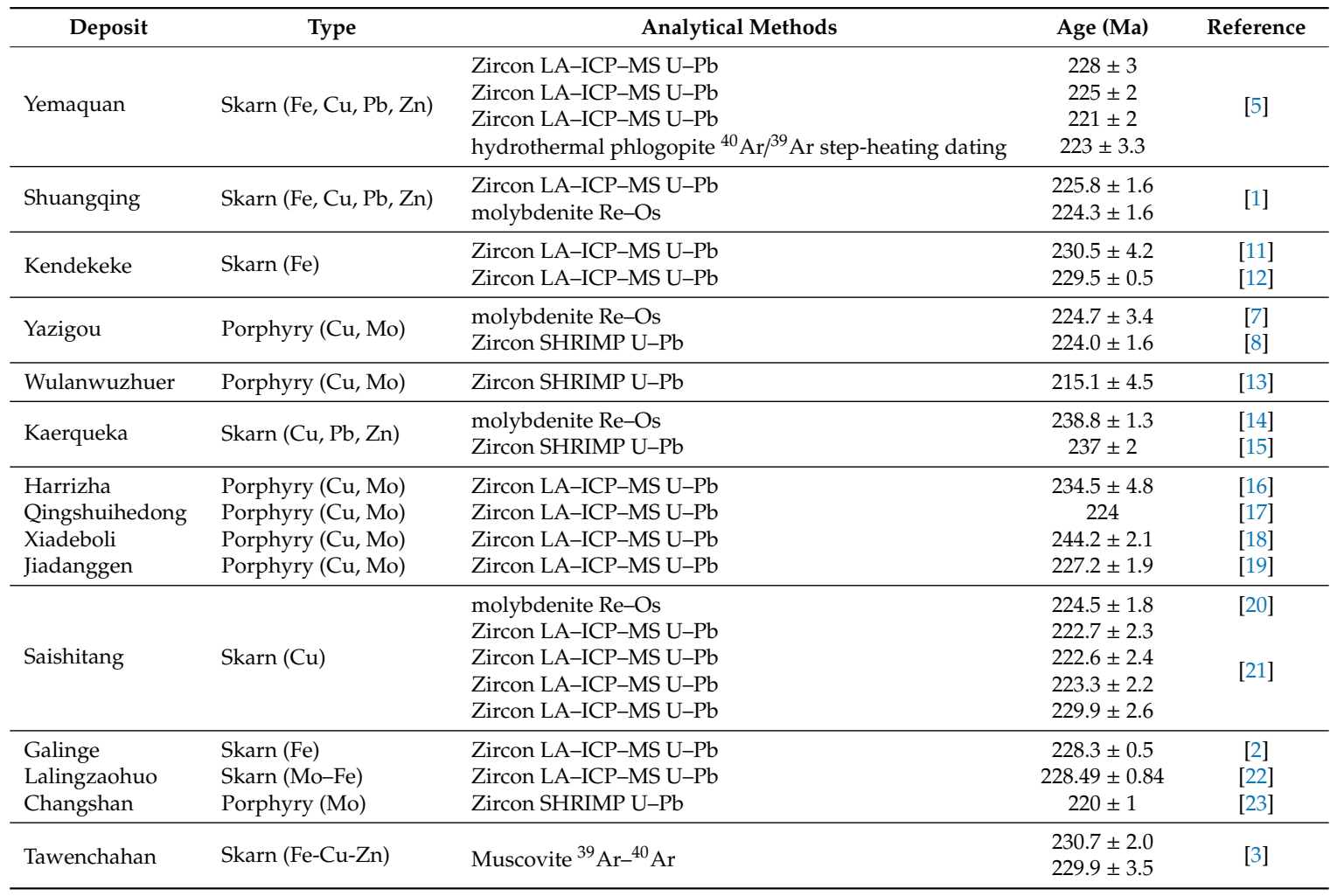

The Hutouya district includes seven major Fe-Cu-Pb-Zn skarn deposits accompanied by Mo-W-Sn-Ag mineralization, which are referred to as ore belts Nos. I-VII (Figure 2). The submitted $\mathrm{Cu}-\mathrm{Pb}-\mathrm{Zn}$ metal resources of ore belts Nos. VII, VI, and II are ca. $60 \times 10^{4} \mathrm{t}, 20 \times 10^{4} \mathrm{t}$, and $5 \times 10^{4} \mathrm{t}$, respectively, indicating they correspond to large-scale deposits and have important economic value [24]. To date, several issues need more reasonable research and interpretation as the prospecting work has deepened; thus, many scholars have become attracted to the discussion of the ore genesis in this deposit [6,24-26]. Although previous studies have investigated igneous rocks in this area, we notice that (1) most of them focused on the monzogranites in the Hutouya [24,26], but the ore-forming granodiorites of ore belts No. I and III have attracted less attention; (2) it still remains unknown whether all the granitic rocks in the Hutouya deposit belong to A-type granite [27]; (3) Sr-Nd-Hf isotopic data for granitoids are urgently needed to compare the magma sources between the ore-forming and non-ore-related granitoids; (4) the petrogenesis of a variety of rock types within the Hutouya deposit has not been systematically studied-especially the crystal tuff of the Elashan Formation-since many $\mathrm{Pb}-\mathrm{Zn}-\mathrm{Ag}$ deposits related to the volcanic strata were discovered [28]; (5) to date, the commonality and difference of ore-forming materials on $\mathrm{S}-\mathrm{Pb}$ isotopes within different ore belts of the Hutouya deposit is unclear.

In this work, in order to address the above issues, we provide new geochronological and geochemical data for the Hutouya deposit, including molybdenite Re-Os dating, zircon LA-ICP-MS $\mathrm{U}-\mathrm{Pb}$ dating, zircon $\mathrm{Hf}$ isotopic compositions, whole rock major and trace elements, and $\mathrm{Sr}-\mathrm{Nd}$ isotopic compositions of ore-related granitoids, non-ore-related granitoids, and crystal tuff, as well as ore-mineral $\mathrm{S}-\mathrm{Pb}$ isotopic compositions, which will place important constraints on the origin of the Hutouya polymetallic skarn deposit. 


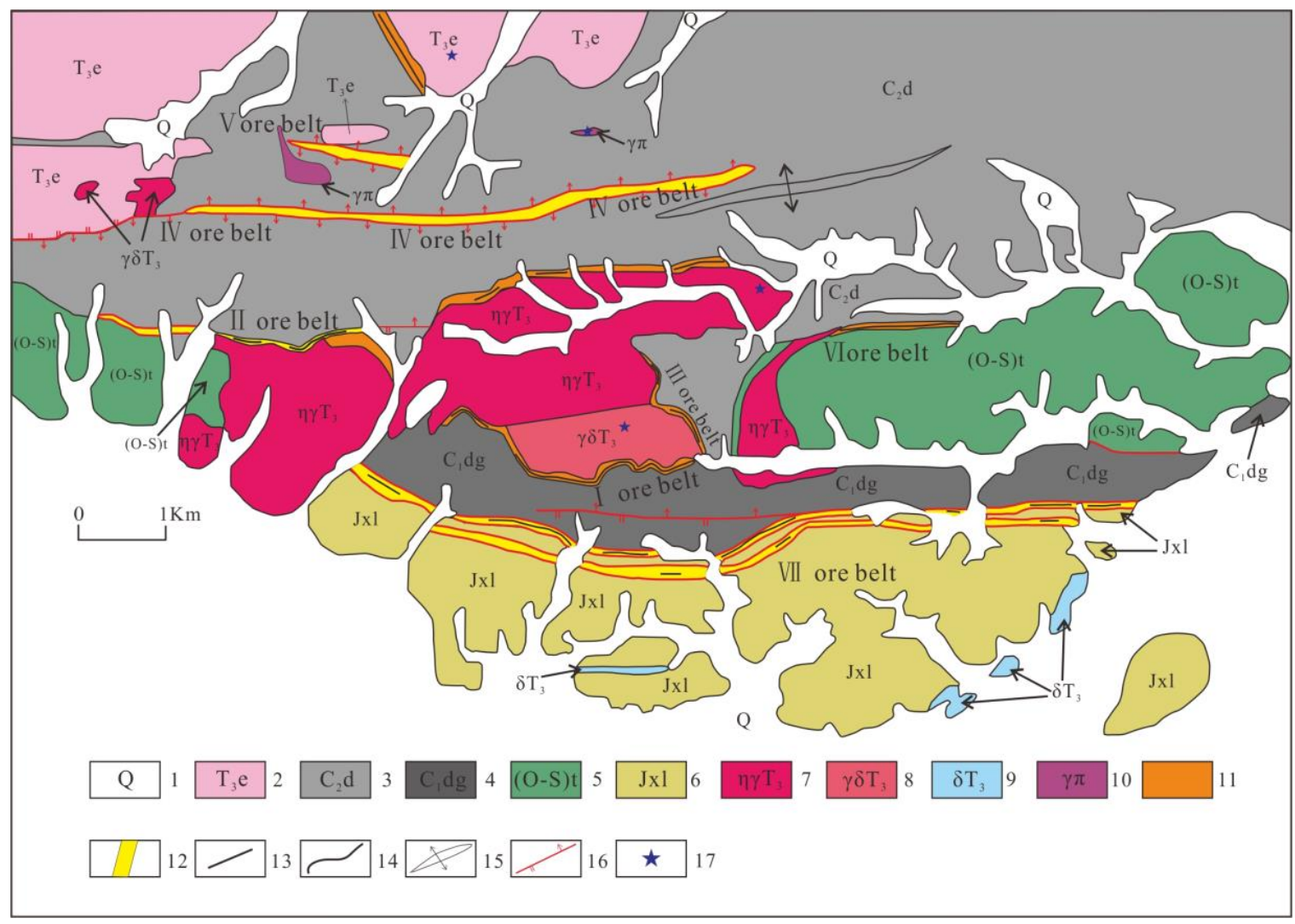

Figure 2. Geological and mineral resources map of the Hutouya deposit (modified after [24]). (1) Quaternary; (2) Upper Triassic Elashan Formation crystal tuff, rhyolitic tuff breccia; (3) Upper Carboniferous Diaosu Formation micrite and microcrystalline-crystalline dolomite, dolomitic limestone, marble, bioclastic limestone, feldspar-quartz sandstone and hornfels; (4) Lower Carboniferous Dagangou Formation marble and crystalline limestone; (5) Cambrian-Ordovician Tanjianshan Group basalt, tuff and cherts; (6) Langyashan Formation (Ji Xian System) calcite dolomite, carbonaceous micritic limestone, marble, quartz sandstone, sericite slate, and siliceous rocks; (7) Late Triassic monzogranite; (8) Late Triassic granodiorite; (9) Late Triassic diorite; (10) Late Triassic granite porphyry; (11) skarn; (12) fractured and altered zone; (13) orebody; (14) stratigraphic boundary; (15) anticline; (16) reverse fault; (17) sampling site.

\section{Regional Geology}

The EKOB extends east-west (E-W) for $>1000 \mathrm{~km}$ in the western part of the Central Orogenic Belt. The respective northern and southern boundaries of the EKOB are marked by the Qaidam Block and Bayan Har-Songpanganzi Terrane (Figure 1a,b), and this belt records the earliest history of assembly of the northern Tibetan Plateau [29,30]. The EKOB is divided into three parts by deep regional fractures: the North Kunlun, Central Kunlun, and South Kunlun belts by the boundaries between these units - from north to south, the North Kunlun fault (NKF), Middle Kunlun fault (MKF), and South Kunlun faults (SKF) [30-32] (Figure 1b). The Precambrian basement of the north Kunlun and Central Kunlun belts is the Paleoproterozoic Jinshuikou Group, which formed at ca. 1800-1600 Ma and underwent granulite facies metamorphism in the Paleozoic [33]. The Precambrian basement of the South Kunlun Belt is composed of the Proterozoic Wanbaogou Group, Kuhai Group, and the early Paleozoic Naij Tal Group [31].

Previous sufficient research works have identified two stages of the Phanerozoic orogeny and related magmatic events in the EKOB: the late Neoproterozoic-Devonian and Carboniferous-Triassic, which correspond to the evolution of the Proto-Tethys and Paleo-Tethys oceans, respectively [31,34-37]. The Hutouya deposit, one of the typical $\mathrm{Cu}-\mathrm{Fe}-\mathrm{Pb}-\mathrm{Zn}$ polymetallic skarn deposits, is located in the 
northwestern EKOB (Figure 1b,c). As previously stated, fragments of the Paleo-Tethyan Oceanic crust have been identified by their 308 Ma MORB-type basaltic lavas and 333 Ma OIB-type gabbro [38-40]. During the Late Permian to Triassic, numerous igneous rocks formed in the subduction and continental collision settings during the Paleo-Tethyan Ocean evolution in the EKOB [41,42]. As previously stated, a large amount of Permian-early Triassic granitoids (ca. 263-240 Ma) with the geochemical characteristics of Andeans-type granites formed in an active continental margin setting within the EKOB [42,43]. In addition, the marine facies sedimentary formations in the forearc basin, including the Upper-Permian Gequ Formation, the Lower-Triassic Hongshuichuan Formation, and Mid-Triassic Naocangjiangou Formation, are believed to be formed in a tectonic setting of ocean subduction within the EKOB related to the evolution of Paleo-Tethys ocean during the Late-Permian to Mid-Triassic [44]. In summary, the Paleo-Tethyan oceanic crust in the EKOB was still in a subduction setting before the Middle Triassic. Subsequently, a continental collision event occurred in the late Middle Triassic (after ca. 240 Ma). Moreover, the Middle to Upper Triassic Babaoshan Formation comprises terrigenous clastic and volcanic rocks in angular unconformity with an underlying marine sequence, indicating that the EKOB entered a collision setting after the late Middle Triassic [20,45]. During the Late Triassic, the EKOB tectonic regime was transformed from a collision compressional to post-collision extensional system following the closure of the Paleo-Tethys Animaqen Ocean [46].

\section{Deposit Geology and Sample Descriptions}

The Hutouya polymetallic deposit is $\approx 345 \mathrm{~km}$ west of Golmud, Qinghai Province, NW China. The strata in the Hutouya mining area are characterized with a large time span, including the mid-Proterozoic Langyashan Formation limestone, Ordovician-Silurian Tanjianshan Formation marble, mafic volcanic rocks with clasolite, Lower Carboniferous Dagan'gou Formation limestone, Upper Carboniferous Di'aosu Formation dolomitic limestone, and marble and Upper Triassic Elashan Formation crystal tuff with rhyolitic tuff breccia. Fold and fault structures occur in the mining area. A near-E-W transpressive fault and fold system formed by north-south (N-S)-directed compression is the ore-controlling structure of the deposit (Figure 2). The Hutouya deposit is a large deposit, including seven main ore belts in the area. Ore belts No. I, II, III, and VI in the middle part of the Hutouya deposit, named the "inner contact skarn zones", emerge as the contact area among the ore-forming intrusions, carbonate strata, and host Fe-Cu-Mo mineralization (Figure 2). In addition, ore belt No. VII, in the southern part of Hutouya deposit, named the "outer contact skarn zone", emerges as the main $\mathrm{Pb}-\mathrm{Zn}$ ore body bounded by carbonate strata and the fracture zones. By contrast, small granodiorite and granite porphyry dykes, without a contact area between granitoids and carbonate strata, appeared in the No. IV and V ore belts in the northern part of the Hutouya deposit, which is different from the No. VII ore belt (Figure 2). Based on the current field geology, a large polymetallic mineralization contact zone between the ore-forming intrusions and the carbonate strata probably exists in the deep part of the No. IV and V ore belts. The specific features of the main ore belts and sample locations are described below:

(1) Ore belt No. I: the ore bodies occur within the granodiorite contact belt with the marble of the Lower Carboniferous Dagan'gou Formation. The No. I ore belt is $2 \mathrm{~km}$ in length and includes four ore bodies. The main ore body is ca. $560 \mathrm{~m}$ in length and ca. $6.6 \mathrm{~m}$ in thickness. The ore bodies generally dip south, and the dip angle is about $20-70^{\circ}$. The magnetite is the dominant opaque mineral in these ores;

(2) Ore belt No. II: the ore bodies occur within the contact zone between the Upper Carboniferous Di'aosu Formation and the monzogranite. Ore belt No. II is $1.5 \mathrm{~km}$ in length and includes 25 ore bodies. The two main ore bodies are 500-600 $\mathrm{m}$ in length and 5-6m in thickness. The ore bodies generally dip south, and the dip angle is about $40 \sim 75^{\circ}$. The chalcopyrite is the dominant opaque mineral in these ores, with minor Fe-Sn-Zn mineralization; 
(3) Ore belt No. III: the mineralization produced in the contact zone between the granodiorite and the Upper Carboniferous Di'aoiosu Formation. Two iron ore bodies have been explored. The ore belt stretches $1.3 \mathrm{~km}$. The alteration types are diopsidization, epidotiation, and choritization;

(4) Ore belt No. VI: the mineralization occurs in the contact zone between the granites (including monzogranite and small granite porphyry veins) and the Upper Carboniferous Di'aosu Formation. The ore belt is $3 \mathrm{~km}$ in length and $10-50 \mathrm{~m}$ in width. Two main mineral bodies ( $\mathrm{Pb}, \mathrm{Zn}$, and $\mathrm{Cu}$ ) have been explored. The length of the two main ore bodies is ca. $830 \mathrm{~m}$, and the thickness of the ore body is about $5 \sim 6 \mathrm{~m}$;

(5) Ore belt No. VI: the ore bodies occurs in the structure fracture of the Upper Carboniferous Di'aosu Formation. The main ore body is $490 \mathrm{~m}$ long, with an average thickness of $3.5 \mathrm{~m}$ and an average zinc grade of $2.52 \%$ and lead grade of $2.30 \%$;

(6) Ore belt No. VII: the ore bodies are located in the E-W trending tectono-fracturing belts in the mid-Proterozoic Langyashan Formation limestone. The No. VII mineralized zone contains four main ore bodies with strata-bound features.

Fresh samples of the ore-forming granitic rocks JR $\left(37^{\circ} 03^{\prime} 52^{\prime \prime} \mathrm{N}, 91^{\circ} 39^{\prime} 32^{\prime \prime} \mathrm{E}\right)$ and DH10 $\left(37^{\circ} 04^{\prime} 24^{\prime \prime} \mathrm{N}, 91^{\circ} 40^{\prime} 06^{\prime \prime} \mathrm{E}\right)$ and the non-ore-related HT $\left(37^{\circ} 05^{\prime} 28^{\prime \prime} \mathrm{N}, 91^{\circ} 39^{\prime} 16^{\prime \prime} \mathrm{E}\right)$ were taken from the Hutouya deposit (Figure 2). The crystal tuff samples $\left(37^{\circ} 05^{\prime} 47^{\prime \prime}\right.$ N, $91^{\circ} 38^{\prime} 17^{\prime \prime}$ E) were also taken to examine the magmatism within the Hutouya deposit. The granodiorite sample (JR) was grayish white in surface outcrops. Microscopic examination revealed a granodiorite mineral composition (Figure 3a) composed mainly of plagioclase $(\approx 45 \%$; $0.6-1.0 \mathrm{~mm})$, alkali feldspar $(\approx 20 \% ; 1.3-1.9 \mathrm{~mm})$, quartz $(\approx 20 \% ; 0.6-1.0 \mathrm{~mm})$, biotite $(\approx 5 \% ; 0.5-1.5 \mathrm{~mm})$ and amphibole $(\approx 10 \% ; 0.3-0.5 \mathrm{~mm})$ with accessory minerals including zircon and apatite. The fresh face of the monzogranite sample (DH10) was light gray with a massive structure (Figure $3 b$ ) and a mineral composition of quartz $(\approx 45 \% ; 0.75-3.0 \mathrm{~mm})$, plagioclase $(\approx 35 \% ; 1-2 \mathrm{~mm})$, alkali feldspar $(\approx 20 \% ; 1.3-1.9 \mathrm{~mm})$ and biotite $(\approx 5 \% ; 0.6-0.75 \mathrm{~mm})$. The granite porphyry sample (HT) exhibited a porphyritic texture. The phenocrysts were mainly plagioclase $(\approx 15 \% ; 0.5-1.0 \mathrm{~mm})$, K-feldspar $(\approx 10 \% ; 0.5-1.0 \mathrm{~mm})$, quartz $(\approx 30 \%)$, and biotite $(\approx 2 \%)$. The groundmass was dominated by felsic minerals, biotite, and minor accessory minerals (Figure 3c). Most plagioclase was subhedral and short columnar in shape, with albite twinning and minor surface kaolinization and carbonate. K-feldspar was mostly subhedral short columnar, with Carlsbad twinning and surface kaolinization. The groundmass mainly comprised microcrystalline quartz and feldspar, and the main accessory minerals were apatite, zircon, and corundum. The Hutouya crustal tuff sample (DH09) was grayish green, with a crystalline-pyroclast tuffaceous texture. Crystal pyroclasts ( $\approx 30 \%)$ included predominantly quartz and pegmatolite (Figure 3d). Quartz pyroclasts were angular with visible embayments.

The main ore mineral samples of the Hutouya deposit were sphalerite, galena, magnetite, and chalcopyrite, followed by molybdenite, arsenopyrite, pyrophyllite, and small amounts of chalcocite, pyrrhotite, and pyrite. The ore mineral analytical samples in this study were collected from the No. IV ore belt and No. VI ore belt within the Hutouya deposit. The ore texture was predominantly metasomatic in structure and exsolution (Figure 3e-i). In particular, the molybdenite was flaky with bending deflection and showed a dissemination structure in the photomicograph (Figure 3e). The chalcopyrite was brass yellow. Microscopic examination revealed an allotriomorphic texture (Figure $3 \mathrm{f}-\mathrm{h}$ ) and milk-drop texture (Figure 3f). The pyrrhotite was cream yellow, tinged slightly pink, and anhedral in texture in the photomicrograph (Figure 3g). The galena was pure white by reflection. Microscopic examination revealed an allotriomorphic granular texture with black delthrium in the surface (Figure $3 \mathrm{~h}$ ). The sphalerite was shown to be dark gray by reflection and exhibited an allotriomorphic graular texture in the photomicrograph (Figure 3f,i). Gangue minerals mainly included calcite, garnet, diopside, fluorite, and quartz. 


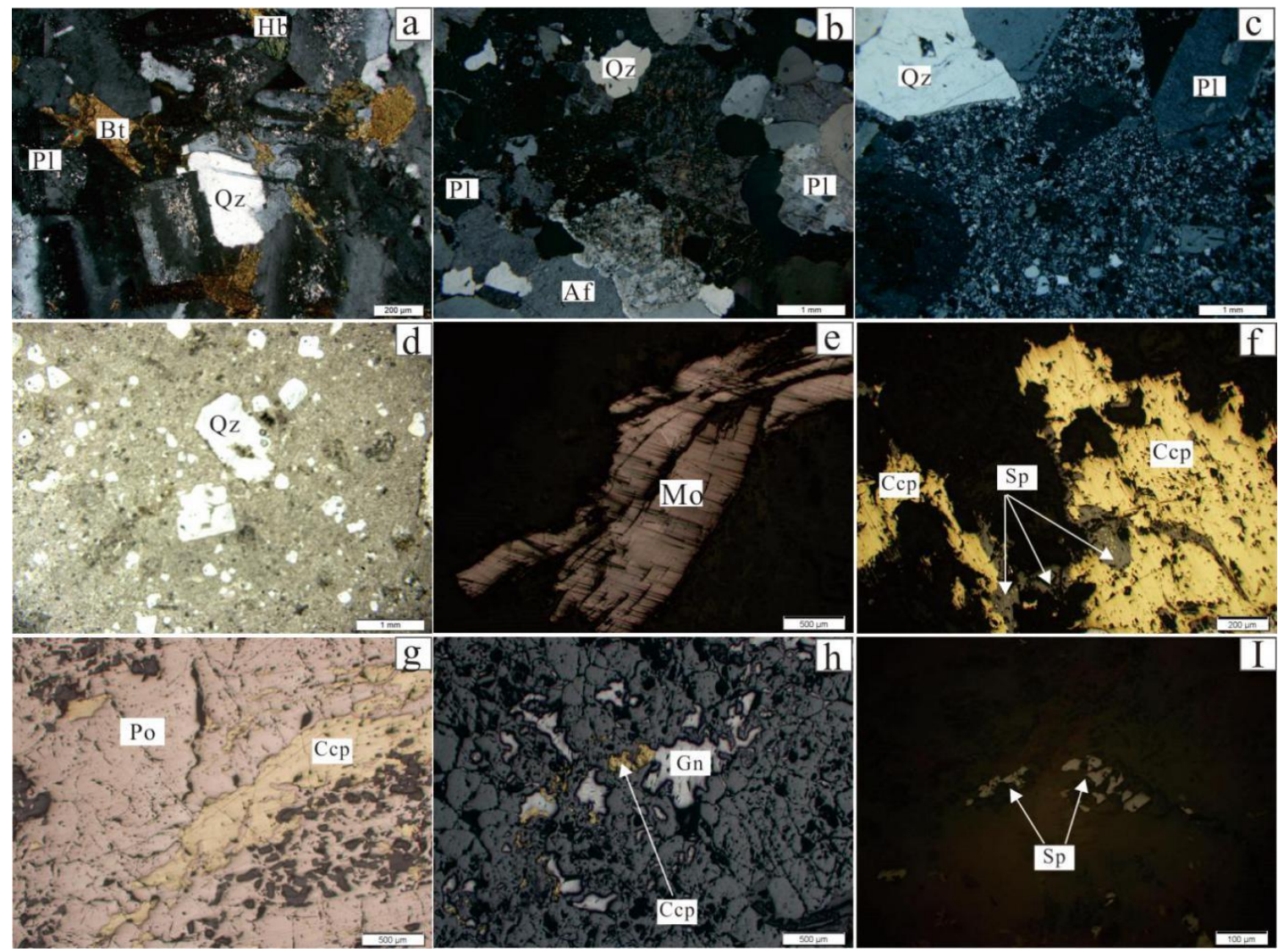

Figure 3. Photomicrographs of Hutouya deposit minerals: (a) granodiorite; (b) monzonitic granite; (c) granite porphyry; (d) crystal tuff; (e) molybdenite; and (f-i) samples used for S-Pb isotopic analyses.

\section{Analytical Methods}

Zircons from the Hutouya granodiorite (sample JR-N) were dated at the State Key Laboratory of Continental Dynamics, Northwest University, Xi an, China. Zircons from the Hutouya granite porphyry (HT-N) and crystal tuff (DH09-N) were dated at the State Key Laboratory of Geological Processes and Mineral Resources (LGPMR), China University of Geosciences, Wuhan, China. Re-Os isotopic analyses were performed at the National Research Center of Geoanalysis, Chinese Academy of Geosciences, Beijing, China. Whole-rock major and trace-element analyses were conducted at the Analysis Center of Jilin University, Jilin Province, China. Hf isotopic compositions of zircons from granodiorite and crystal tuff were determined at the State Key Laboratory of Geological Processes and Mineral Resources (LGPMR), China University of Geosciences, Wuhan, China. Hf isotopic compositions of zircons from the granite porphyry were determined at the Beijing Yanduzhongshi Testing Technology, Beijing, China. Whole-rock Sr-Nd isotopic analyses of the Hutouya monzogranite and crystal tuff were undertaken at the Analytical Laboratory of the Beijing Research Institute of Nuclear Industry, Beijing. Sulfur and Lead isotopic analyses were undertaken at the Analysis and Test Research Center, Beijing Geological Research Institute of Nuclear Industry, Beijing. The analytical techniques used in the testing are described in Appendix A. 


\section{Results}

\subsection{Geochronology}

\subsubsection{Zircon U-Pb Dating}

The results of zircon U-Pb dating are given in Supplementary Material Table S1, and their concordia diagrams are presented in Figure 4a-c. Zircons from the Hutouya granitic rocks and crystal tuff were generally light gray and columnar. All analyzed zircons were euhedral with lengths of $70-120 \mu \mathrm{m}$ and aspect ratios of 1-3. Their oscillatory growth zoning indicated a magmatic origin [47]. The ${ }^{206} \mathrm{~Pb} /{ }^{238} \mathrm{U}$ ages of zircons from sample JR-N ranged from 232 to $221 \mathrm{Ma}$, with a weighted-mean age of 227.1 $\pm 3.6 \mathrm{Ma}$ (MSWD = 0.13; $\mathrm{n}=16$; Figure 4a). Zircons from the Hutouya granite porphyry (sample HT-N) yielded ${ }^{206} \mathrm{~Pb} /{ }^{238} \mathrm{U}$ ages of $226-217 \mathrm{Ma}$ and a weighted-mean age of $222.1 \pm 1.0 \mathrm{Ma}$ (MSWD $=0.66 ; n=26)$ (Figure 4b). Zircons from the Hutouya crystal tuff (sample DH09-N) displayed prismatic forms, with ${ }^{206} \mathrm{~Pb} /{ }^{238} \mathrm{U}$ ages of $233-215 \mathrm{Ma}$ and a weighted-mean age of $222.7 \pm 2.5 \mathrm{Ma}$ (MSWD $=0.34 ; \mathrm{n}=18$ ) (Figure $4 \mathrm{c}$ ). These results together indicate that the crystallization of the Hutouya granitic rocks and the eruption of the crystal tuff both occurred during the Late Triassic.
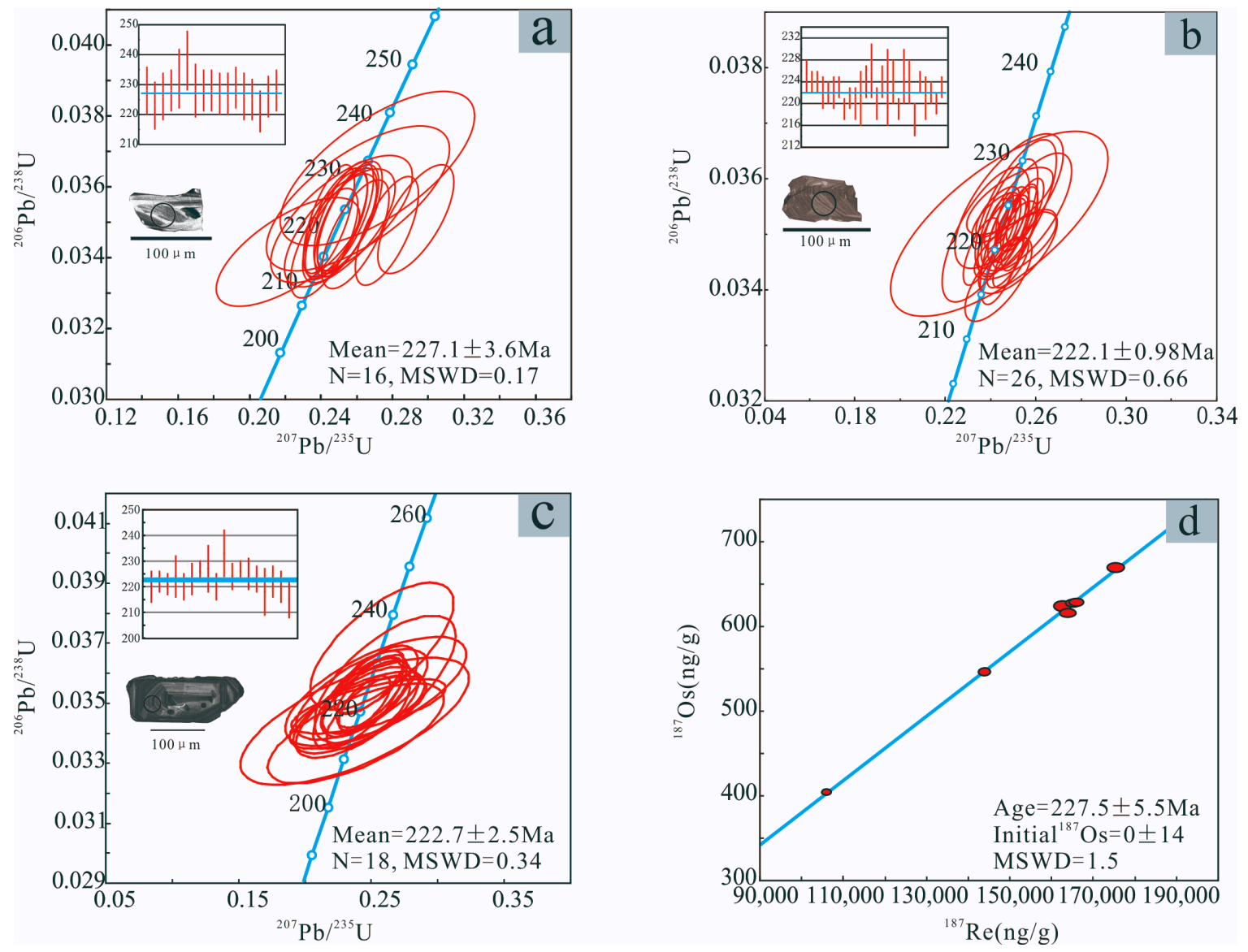

Figure 4. Zircon U-Pb concordia diagrams $(\mathbf{a}-\mathbf{c})$ and molybdenite Re-Os isochron model ages (d) of the Hutouya deposit.

\subsubsection{Molybdenite Re-Os Dating}

Re-Os analysis results for seven molybdenite samples are summarized in Supplementary Material Table S2. Re and ${ }^{187}$ Os contents were $169.0-278.8$ ppm and 403.8-669.4 ppm, respectively. Common Os $(\approx 0.01 \mathrm{ppb})$ may have been derived from analytical artifacts and was negligible compared with ${ }^{187} \mathrm{Os}$. Therefore, the molybdenite Re-Os ages were considered reliable [48]. The seven molybdenite samples 
from skarn ores yielded consistent model ages of 230-225 Ma (Supplementary Material Table S2), with an Re-Os isochron age of $227 \pm 6 \mathrm{Ma}$ (MSWD $=1.5$ ) and an initial ${ }^{187}$ Os content of $0 \pm 14 \mathrm{ppm}$ (Figure 4d). Furthermore, the Re content is commonly used to trace ore-forming materials [49], and the higher Re contents (169-278 ppm) recorded here may imply the involvement of mantle underplating [50].

\subsection{Whole-Rock Major and Trace-Element Compositions}

Whole-rock major and trace-element compositions of 23 representative samples of granitic rocks and crystal tuff are given in Supplementary Material Table S3 and are described separately for each rock type below.

\subsubsection{Ore-Forming Granodiorite and Monzogranite}

The six analyzed samples of the Hutouya granodiorite have $\mathrm{SiO}_{2}$ and $\mathrm{Al}_{2} \mathrm{O}_{3}$ contents of 62.40-65.10 wt \% and 16.38-16.83 wt \%, respectively, and a high alkali content $\left(\mathrm{Na}_{2} \mathrm{O}=4.43-4.69 \mathrm{wt} \%\right.$; $\mathrm{K}_{2} \mathrm{O}=2.93-3.41 \mathrm{wt} \% ; \mathrm{K}_{2} \mathrm{O}+\mathrm{Na}_{2} \mathrm{O}=7.59-7.92 \mathrm{wt} \%$ ) with $\mathrm{K}_{2} \mathrm{O} / \mathrm{Na}_{2} \mathrm{O}$ ratios of $1.32-1.59$. These samples are plot in the high- $\mathrm{K}$ calc-alkaline field in a $\mathrm{SiO}_{2}-\mathrm{K}_{2} \mathrm{O}$ diagram (Figure $5 \mathrm{a}$ ). Their $\mathrm{A} / \mathrm{CNK}$ and $\mathrm{A} / \mathrm{NK}$ ratios $\left(\mathrm{A}=\mathrm{Al}_{2} \mathrm{O}_{3} ; \mathrm{C}=\mathrm{CaO} ; \mathrm{N}=\mathrm{Na}_{2} \mathrm{O} ; \mathrm{K}=\mathrm{K}_{2} \mathrm{O}\right.$, molar values $)$ are in the ranges of 1.00-1.02 and $1.47-1.55$, respectively, plotting in the metaluminous to weakly peraluminous region (Figure $5 \mathrm{~b}$ ). The samples display subparallel, right-tilting, chondrite-normalized rare Earth element (REE) patterns (Figure 6a) and have high total REE contents (REE $=76.9-92.1 \mathrm{ppm}$ ). The fractionation of light REEs (LREEs) and heavy REEs (HREEs) is obvious $\left((\mathrm{La} / \mathrm{Yb})_{\mathrm{N}}=5.66-7.92\right)$. The samples display weak positive $\mathrm{Eu}$ anomalies $\left(\mathrm{Eu} / \mathrm{Eu}^{*}=1.09-1.44\right)$. In a primitive-mantle-normalized trace-element spider diagram (Figure $6 \mathrm{~b}$ ), the rocks are enriched in $\mathrm{Rb}, \mathrm{Ba}, \mathrm{K}$, and other large-ion lithophile elements (LILEs) and depleted in high-field-strength elements (HFSEs; e.g., $\mathrm{Nb}, \mathrm{Ta}, \mathrm{P}$, and Ti).
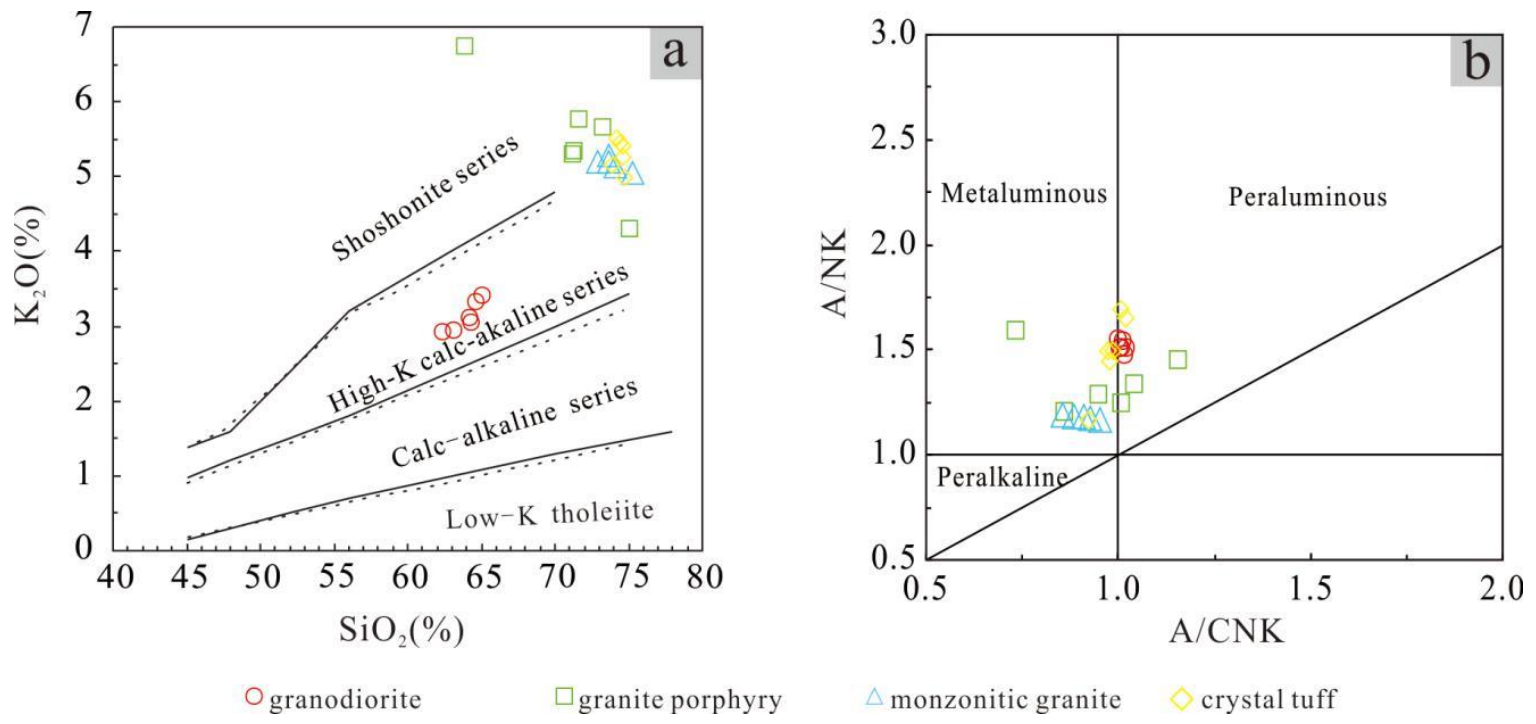

Figure 5. Discrimination diagrams for granitic rocks and crystal tuff of the Hutouya deposit: (a) $\mathrm{K}_{2} \mathrm{O}-\mathrm{SiO}_{2}$ [51]; (b) A/NK-A/CNK [52].

The monzogranite samples showed $\mathrm{SiO}_{2}, \mathrm{Na}_{2} \mathrm{O}$ and $\mathrm{K}_{2} \mathrm{O}$ contents of $72.93-75.24 \mathrm{wt} \%, 2.85-3.16 \mathrm{wt} \%$ and 5.06-5.27 wt \%, respectively, with $\mathrm{Na}_{2} \mathrm{O} / \mathrm{K}_{2} \mathrm{O}$ ratios of $0.56-0.61$. They are plotted in the high- $\mathrm{K}$ calc-alkaline field in a $\mathrm{SiO}_{2}-\mathrm{K}_{2} \mathrm{O}$ diagram (Figure 5a). Their $\mathrm{A} / \mathrm{CNK}$ and $\mathrm{A} / \mathrm{NK}$ ratios are in the ranges $0.86-0.95$ and 1.17-1.19, respectively, indicating a metaluminous to weakly peraluminous nature (Figure $5 b$ ). The samples exhibited subparallel chondrite-normalized REE patterns, which are characterized by fractionation between LREEs and HREEs, with $(\mathrm{La} / \mathrm{Yb})_{\mathrm{N}}$ ratios of 3.67-6.99 and strong 
negative Eu anomalies $\left(\mathrm{Eu} / \mathrm{Eu}^{*}=0.54-0.64\right)$ (Figure 6a). The rocks were enriched in LILEs but depleted in HFSEs, with negative Ba, Sr, $\mathrm{P}$, and Ti anomalies (Figure 6b).
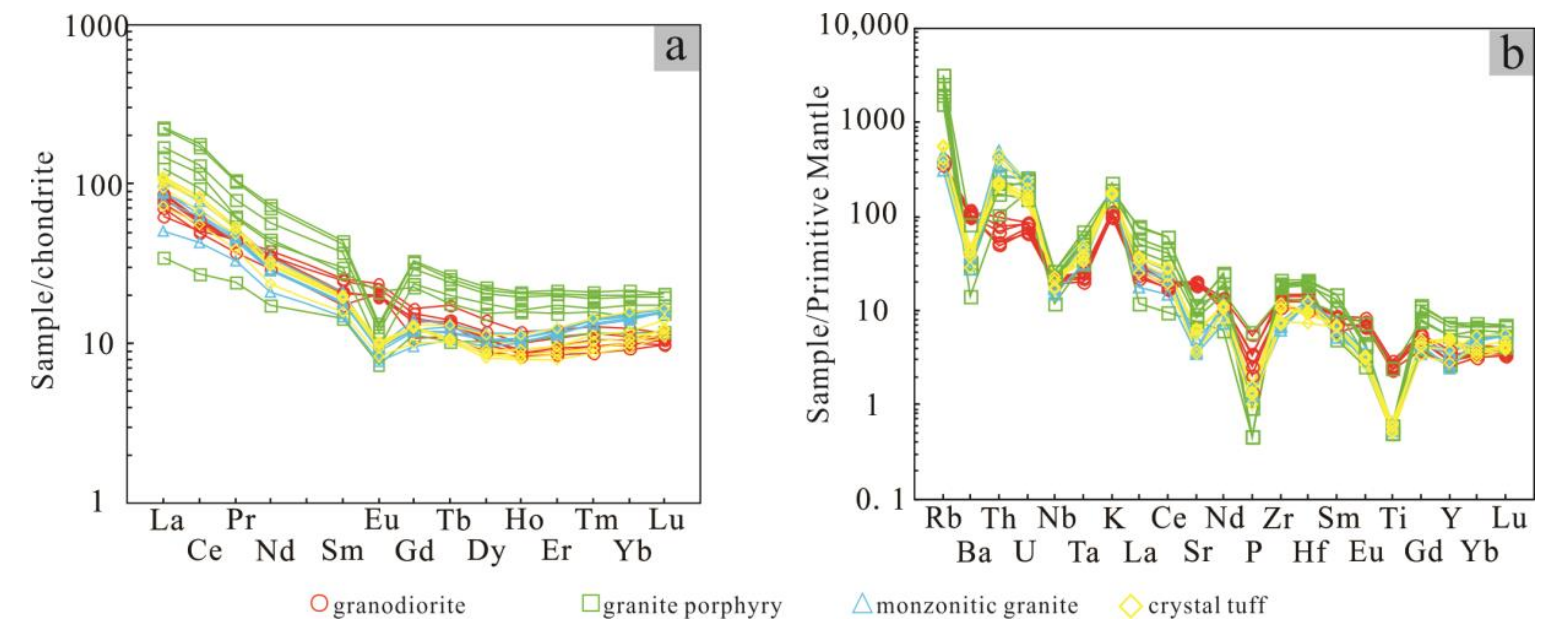

Figure 6. (a) Chondrite-normalized rare Earth element (REE) patterns (chondrite REE values from [53]); and (b) primitive-mantle-normalized trace-element spider diagram (primitive-mantle values from [54]) for granitic rocks and crystal tuff of the Hutouya deposit.

\subsubsection{Non-Ore-Related Granite Porphyry and Crystal Tuff}

The granite porphyry samples had $\mathrm{SiO}_{2}, \mathrm{~K}_{2} \mathrm{O}, \mathrm{MgO}, \mathrm{TiO}_{2}$ and $\mathrm{P}_{2} \mathrm{O}_{5}$ contents of $63.83-73.26 \mathrm{wt} \%$, 4.31-6.74 wt \%, 0.51-1.24 wt \%, 0.11-0.53 wt \%, and 0.11-0.13 wt \%, respectively. They had high total-alkali contents $\left(\mathrm{K}_{2} \mathrm{O}+\mathrm{Na}_{2} \mathrm{O}=7.03-8.53 \mathrm{wt} \%\right)$ with $\mathrm{K}_{2} \mathrm{O} / \mathrm{Na}_{2} \mathrm{O}$ ratios of $0.20-0.63$, plotting in the high-K calc-alkaline shoshonite field in a $\mathrm{SiO}_{2}-\mathrm{K}_{2} \mathrm{O}$ diagram (Figure 5a). The samples had A/CNK ratios of $0.73-1.16$, indicating metaluminous to weakly peraluminous characteristics. Their REE contents ranged from 48.3 to $238.6 \mathrm{ppm}$ (mean $164.6 \mathrm{ppm}$ ), including LREE contents of 38.01-215.6 ppm. The granite porphyry samples had similar chondrite-normalized REE patterns (Figure 6a), exhibiting negative $\mathrm{Eu}$ anomalies $\left(\mathrm{Eu} / \mathrm{Eu}^{*}=0.34-0.74\right.$; Figure 6a) and LREE enrichment with a marked differentiation of LREEs.

The crystal tuff samples had $\mathrm{SiO}_{2}$ contents of 73.85-74.75 wt \% and appeared metaluminous to weakly peraluminous in an $\mathrm{A} / \mathrm{CNK}-\mathrm{A} / \mathrm{NK}$ diagram (Figure $5 \mathrm{~b}$ ). All samples had total medium REE ( $\Sigma$ MREE) contents of 78.1-111.5 ppm (mean 101.4 ppm). In the chondrite-normalized REE plots (Figure 6a), they display a strong enrichment in LREEs and depletion in HREEs (mean $\left.(\mathrm{La} / \mathrm{Yb})_{\mathrm{N}}=9.04\right)$. In the primitive-mantle-normalized trace-element spider diagram (Figure 6b), all samples display enrichment in LILEs (e.g., Rb, Th, U, and REEs), strong depletion in HFSEs (e.g., $\mathrm{Nb}, \mathrm{Ta}$, Ti, and P) and weak negative $\mathrm{Sr}$ anomalies. They had strong negative $\mathrm{Eu}$ anomalies $\left(\mathrm{Eu} / \mathrm{Eu}^{*}=0.58-0.63\right)$, which is indicative of the possible crystal fractionation of plagioclase.

\subsection{Sr-Nd Isotopic Compositions}

The results of Sr-Nd isotopic analyses of the Hutouya monzogranite and crystal tuff are given in Supplementary Material Table S4 and plotted in Figure $7 \mathrm{~b}$. The monzogranite samples had ${ }^{87} \mathrm{Sr} /{ }^{86} \mathrm{Sr}$ ratios in the range of $0.731771-0.734463$, with initial ${ }^{87} \mathrm{Sr} /{ }^{86} \mathrm{Sr}$ ratios $\left(\mathrm{I}_{\mathrm{Sr}}\right)$ of $0.70635-0.70798$. Their ${ }^{143} \mathrm{Nd} /{ }^{144} \mathrm{Nd}$ ratios were in the range $0.51228-0.51319$ with $\varepsilon \mathrm{Nd}(\mathrm{t})$ values of -5.01 to -4.11 and $\mathrm{T}_{\mathrm{DM} 2}$ model ages of $1406-1369 \mathrm{Ma}$. The crystal tuff samples had ${ }^{87} \mathrm{Sr} /{ }^{86} \mathrm{Sr}$ ratios in the range of $0.732635-0.739379$, with initial ${ }^{87} \mathrm{Sr} /{ }^{86} \mathrm{Sr}$ ratios $\left(\mathrm{I}_{\mathrm{Sr}}\right)$ of $0.70068-0.71639$. Their ${ }^{143} \mathrm{Nd} /{ }^{144} \mathrm{Nd}$ ratios were in the range of $0.512252-0.512291$ with $\varepsilon \mathrm{Nd}(\mathrm{t})$ values of -5.43 to -4.69 and $\mathrm{T}_{\mathrm{DM} 2}$ model ages of 1442-1382 Ma. 

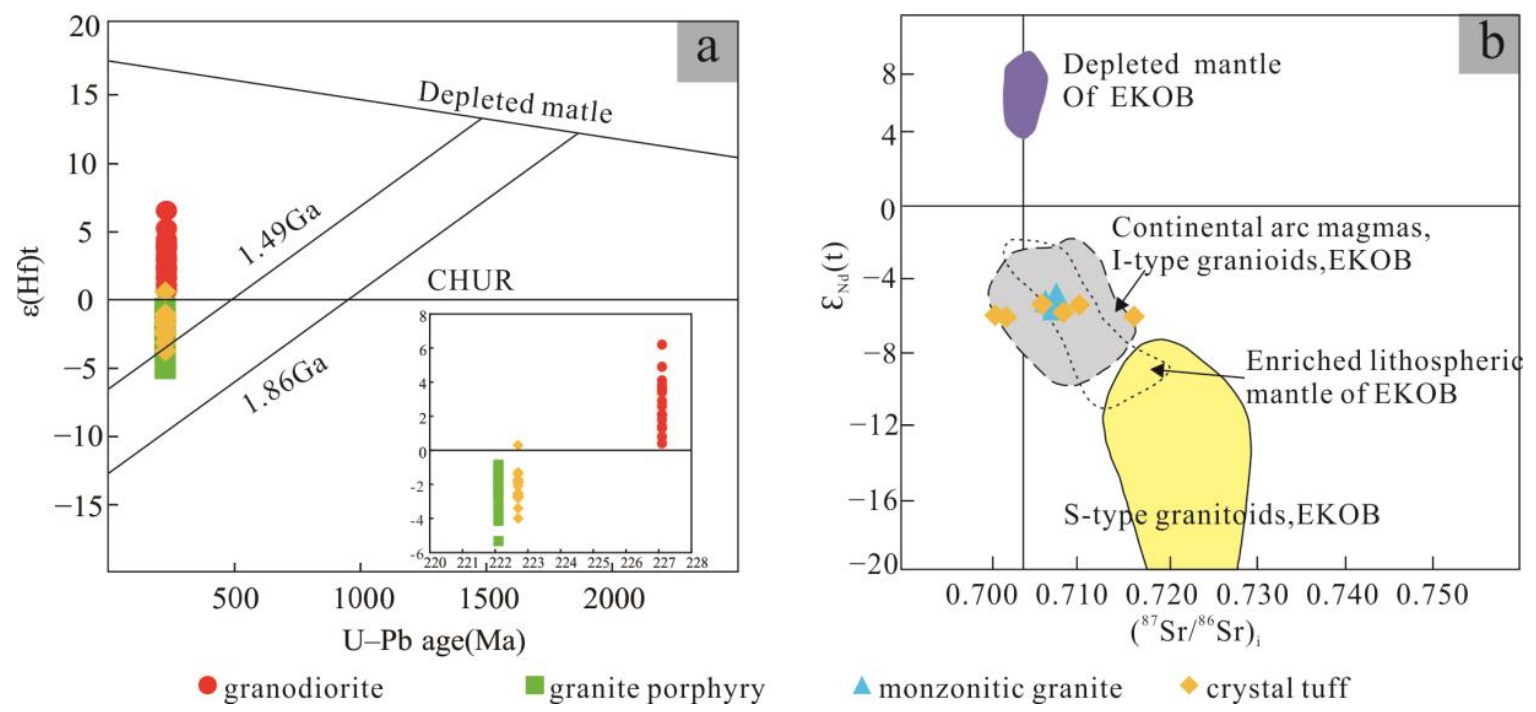

Figure 7. (a) $\varepsilon \mathrm{Hf}(\mathrm{t})-$ Age plot for zircons from granitic rocks and crystal tuff; (b) $\varepsilon \mathrm{Nd}(\mathrm{t})-\left({ }^{87} \mathrm{Sr} /{ }^{86} \mathrm{Sr}\right) \mathrm{t}$ diagram (after [55]) for monzonitic granite and crystal tuff of the Hutouya deposit.

\subsection{Zircon Hf Isotopic Compositions}

Hf isotopic data for zircons from the Hutouya granitic rocks and crystal tuff are given in Supplementary Material Table S5 and plotted in Figure 7a. All magmatic zircons from the granodiorite had initial ${ }^{176} \mathrm{Hf} /{ }^{177} \mathrm{Hf}$ ratios of $0.282655-0.282755$, positive $\varepsilon \mathrm{Hf}(\mathrm{t})$ values of $0.4-6.2$, and $\mathrm{T}_{\mathrm{DM} 2}$ ages of 1087-930 Ma, indicating that the primary magma was derived from Meso-Neoproterozoic juvenile components. Eighteen magmatic zircons from the crystal tuff were analyzed for Lu-Hf isotopes, yielding initial ${ }^{176} \mathrm{Hf} /{ }^{177} \mathrm{Hf}$ ratios of $0.282524-0.282591, \varepsilon \mathrm{Hf}(\mathrm{t})$ values of -4.0 to +0.3 , and $\mathrm{T}_{\mathrm{DM} 2}$ ages of 1345-1199 Ma, indicating magma sourced from Mesoproterozoic and reworked crustal materials. Fifteen magmatic zircons from the granite porphyry were also analyzed for Lu-Hf isotopes, yielding initial ${ }^{176} \mathrm{Hf} /{ }^{177} \mathrm{Hf}$ ratios of $0.282524-0.282607, \varepsilon \mathrm{Hf}(\mathrm{t})$ values of -5.3 to -0.9 , and $\mathrm{T}_{\mathrm{DM} 2}$ ages of $1312-1106 \mathrm{Ma}$. The predominantly negative $\varepsilon \mathrm{Hf}(\mathrm{t})$ values indicate that the magma was derived from reworked Mesoproterozoic crustal components.

\subsection{Ore-Mineral S-Pb Isotopic Compositions}

$\mathrm{S}$ isotopic data for 15 ore-mineral samples from the Hutouya No. IV and No. VI ore belts are presented in Supplementary Material Table S6. Together with the previous data, $\delta^{34} \mathrm{~S}_{\mathrm{V}-\mathrm{CDT}}$ values from the northern, middle, and southern Hutouya deposit were in the ranges $+0.8 \%$ o to $+4.8 \%$ o (mean $2.2 \%$; $\mathrm{n}=21),+0.6 \%$ o to $+6.4 \%$ o (mean $4.3 \%$; $\mathrm{n}=24$ ), and $+1.6 \%$ to $+9.8 \%$ (mean $7.6 \%$; $\mathrm{n}=16$ ), respectively.

$\mathrm{Pb}$ isotopic compositions for the 15 sulfide mineral samples together with previous published data are given in Supplementary Material Table S7. All of the 51 sulfides had ${ }^{206} \mathrm{~Pb} /{ }^{204} \mathrm{~Pb},{ }^{207} \mathrm{~Pb} /{ }^{204} \mathrm{~Pb}$, and ${ }^{208} \mathrm{~Pb} / 204 \mathrm{~Pb}$ ratios of $18.116-19.502,15.560-15.813$, and 38.186-39.021, respectively. The uniformity of these ratios indicates a homogeneous common $\mathrm{Pb}$ composition, with the deposit being derived from a relatively stable $\mathrm{Pb}$ source.

\section{Discussion}

\subsection{Age of Mineralization}

Accurate dating is crucial to the understanding of an ore deposit, and here, we discuss new dating results for the granitic rocks, crystal tuff, and molybdenite of the Hutouya deposit. Our zircon U-Pb dating of the crystal tuff indicates that its eruption occurred at $222.7 \pm 2.5 \mathrm{Ma}$, and our zircon U-Pb dating of the granitic rocks indicates the emplacement and crystallization of granodiorite and granite porphyry at $227.1 \pm 3.6 \mathrm{Ma}$ and $222.1 \pm 1.0 \mathrm{Ma}$, respectively. The molybdenite Re-Os isochron ages 
$(227.5 \pm 5.5 \mathrm{Ma})$ and zircon $\mathrm{U}-\mathrm{Pb}$ dating of granodiorite are concordant within error at ca. 227.5 Ma. Thus, these ages indicate that magmatism and related skarn mineralization in the Hutouya deposit occurred during the Late Triassic. As stated previously, the closure temperature of the zircon U-Pb isotopic dating system and the Re-Os isotopic dating system is $800{ }^{\circ} \mathrm{C}$ and $500 \pm 50^{\circ} \mathrm{C}[56,57]$. Therefore, the formation of the Hutouya deposit is related to the separation and exsolution of ore-forming fluids that occurred after the magma cooled rapidly from 800 to $500 \pm 50{ }^{\circ} \mathrm{C}$ at ca. $227 \mathrm{Ma}$.

\subsection{Genetic Types of the Igneous Rocks}

The identification of the genetic type of felsic igneous rocks is critical to the understanding of their magma sources, magmatic evolution and tectonic settings [58]. Granitic rocks can be classified as either I, S, or A-types $[59,60]$. Our granodiorite, granite porphyry, and monzogranite samples had high $\mathrm{K}$ contents, low $(\mathrm{Zr}+\mathrm{Nb}+\mathrm{Ce}+\mathrm{Y})$ contents, and low $(10,000 \times \mathrm{Ga} / \mathrm{Al})$ ratios. In $\left(\left(\mathrm{Na}_{2} \mathrm{O}+\mathrm{K}_{2} \mathrm{O}\right) / \mathrm{CaO}\right)$ $-(10,000 \times \mathrm{Ga} / \mathrm{Al})$ (Figure $8 \mathrm{a})$ and $\left(\left(\mathrm{Na}_{2} \mathrm{O}+\mathrm{K}_{2} \mathrm{O}\right) / \mathrm{CaO}\right)-(\mathrm{Zr}+\mathrm{Nb}+\mathrm{Ce}+\mathrm{Y})$ (Figure 8b) diagrams, all samples were plotted in the I and S-type granite and non-fractionated granite fields, respectively.
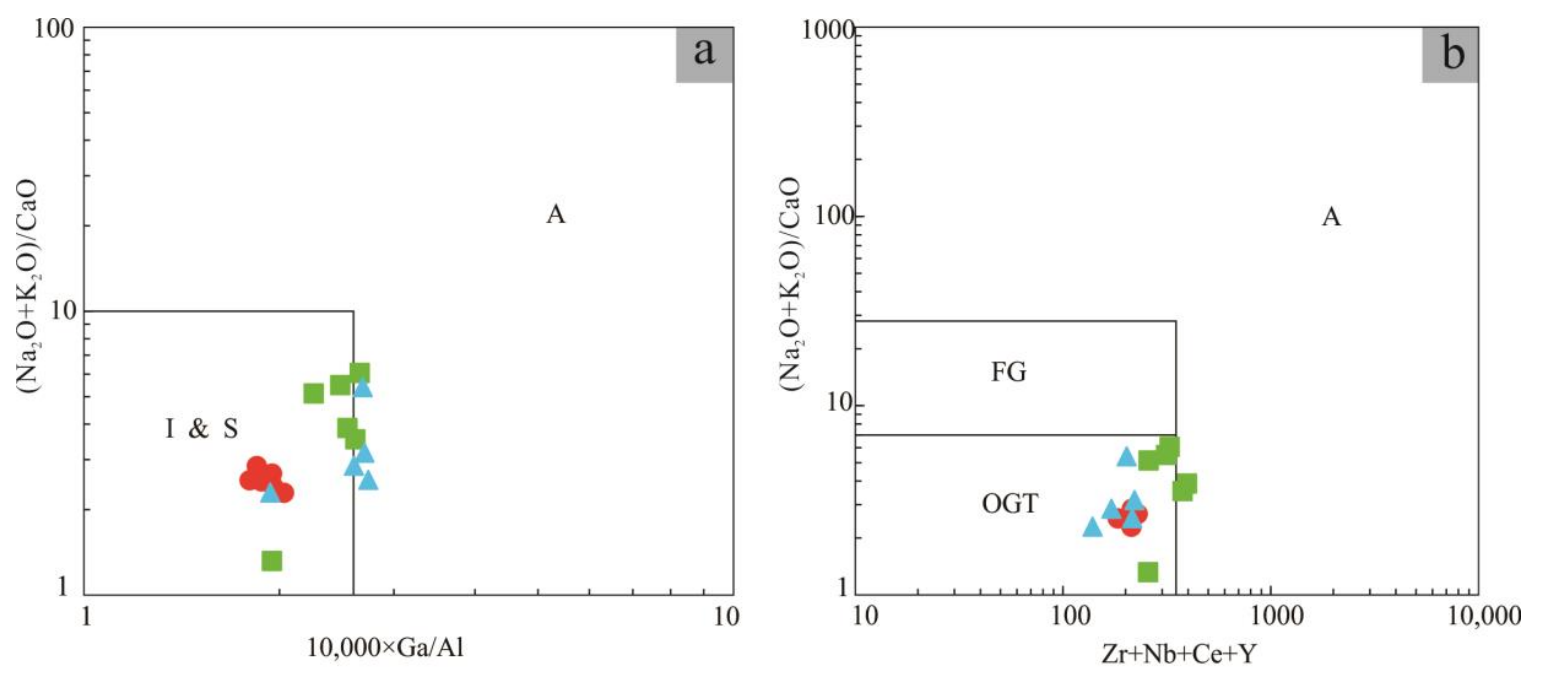

$$
\text { granodiorite } \quad \text { granite porphyry } \quad \Delta \text { monzonitic granite }
$$

Figure 8. (a) $\left(\mathrm{Na}_{2} \mathrm{O}+\mathrm{K}_{2} \mathrm{O}\right) / \mathrm{Ca}-(10,000 \times \mathrm{Ga} / \mathrm{Al})$ and $(\mathbf{b})\left(\mathrm{Na}_{2} \mathrm{O}+\mathrm{K}_{2} \mathrm{O}\right) / \mathrm{CaO}-(\mathrm{Zr}+\mathrm{Nb}+\mathrm{Ce}+\mathrm{Y})$ diagrams for Hutouya granites and crystal tuff (FG-fractionated granites; OGT-unfractionated granites; after [60]).

A-type granites generally consist of alkaline minerals such as richterite, aegirine, and fayalite, unlike the granitic rocks of the Hutouya deposit, which are therefore not A-type granites. The mean $\mathrm{A} / \mathrm{CNK}$ ratios of the Hutouya granitic rocks is 0.96 , unlike S-type granites (A/CNK > 1.1) [61]. The solubility of $\mathrm{P}_{2} \mathrm{O}_{5}$ is high in strongly peraluminous melts but low in metaluminous or weakly peraluminous melts. Therefore, the $\mathrm{P}_{2} \mathrm{O}_{5}$ content increases in peraluminous S-type melts during crystal fractionation but decreases in I-type melts [62-64]. The Hutouya granitic rock samples generally have high $\mathrm{SiO}_{2}$ contents and are high- $\mathrm{K}$ calc-alkaline and metaluminous to weakly peraluminous rocks. Additionally, their trends are not in accordance with S-type granites in the $\mathrm{P}_{2} \mathrm{O}_{5}-\mathrm{SiO}_{2}$ diagram; on the contrary, they resemble the I-type granite trend (Figure 9h). The lack of Al-rich minerals such as cordierite and muscovite also supports their I-type rather than S-type origin [61]. Moreover, the low initial ${ }^{87} \mathrm{Sr} /{ }^{86} \mathrm{Sr}$ ratios of monzonitic granite ranging from 0.70635 to 0.70798 are clearly different from S-type granites (initial ${ }^{87} \mathrm{Sr} /{ }^{86} \mathrm{Sr}>0.710$ ) [65]. Therefore, we conclude that the Hutouya granitoids are I-type granites. 

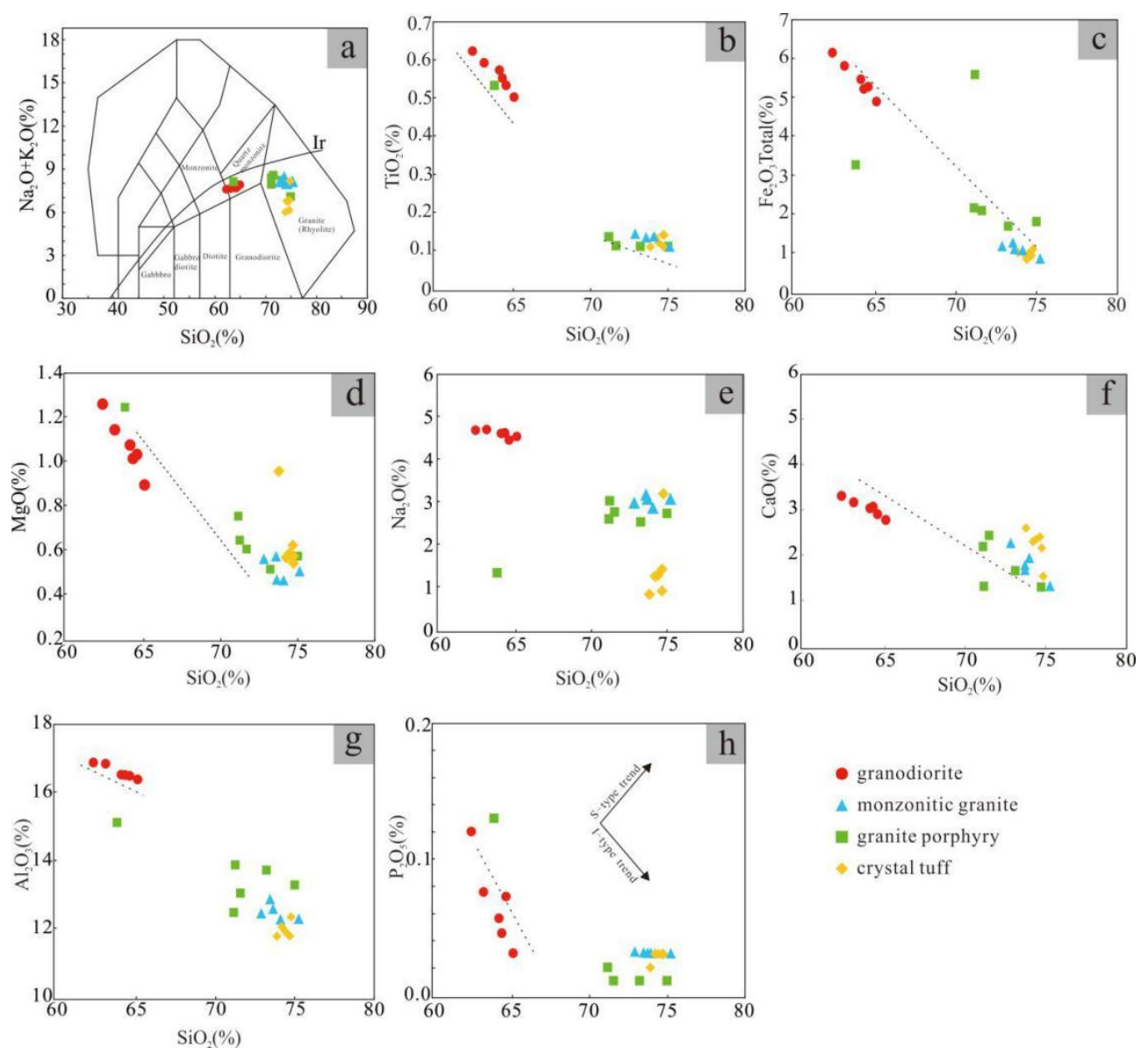

- granodiorite

$\Delta$ monzonitic granite

aranite porphyry

* crystal tuff

Figure 9. (a-h) Plots of major-element contents vs. $\mathrm{SiO}_{2}$ content for Hutouya granitic rocks and crystal tuff.

\subsection{Magma Sources and Petrogenesis}

As mentioned above, all the igneous rocks from the Hutouya deposit are high potassium calc-alkaline to shoshonite series, metaluminous to weakly peraluminous I-typed granites. Generally, the calc-alkaline I-type granites can be generated by the partial melting of mafic to intermediate igneous rocks [66] by mantle-derived basaltic magmas, which underwent extensive assimilation and fractional crystallization [67] or by the mixing of crust and mantle-derived magma [68].

\subsubsection{Ore-Forming Granodiorite and Monzogranite}

The granodiorite and monzogranite samples from the Hutouya deposit all showed high $\mathrm{SiO}_{2}$ (62.40-75.24 wt \%) and $\mathrm{Al}_{2} \mathrm{O}_{3}(12.15-16.83 \mathrm{wt} \%)$ contents; low $\mathrm{MgO}(0.45-1.26 \mathrm{wt} \%), \mathrm{Cr}(2.03-10.48 \mathrm{ppm})$, Co (0.80-6.94 ppm), and Ni (3.19-8.21 ppm) contents (Supplementary Material Table S3); positive Rb and $\mathrm{K}$ anomalies; and negative $\mathrm{Nb}, \mathrm{Ta}, \mathrm{P}$, and $\mathrm{Ti}$ anomalies (Figure $6 \mathrm{~b}$ ). Such characteristics are consistent with crust-derived rocks [69,70]. In addition, the granodiorite and monzogranite samples were unassociated with any contemporaneous gabbros and basalts in the Hutouya area. All these factors exclude the possibility that they could be generated directly by the partial melting of mantle peridotite. Moreover, experimental studies indicate that the $\mathrm{Mg}^{\#}$ value is an effective way to evaluate the magma melts. In general, the dehydration melting of the basaltic lower crust generates low $\mathrm{Mg}^{\#}$ $(<40)$ melts, whereas the melts with mantle components involved can produce $\mathrm{Mg}^{\#}(>40)[71,72]$. According to the results, the granodiorite samples had a relatively low $\mathrm{Mg}^{\#}$ value ranging from 27 to 29 , which indicates that the melts were derived from mafic lower crust. Notably, the $\mathrm{Mg}^{\#}$ value of the monzogranite samples ranged from 42 to 55, which likely suggests an involvement of 
mantle-derived components. Furthermore, the $\mathrm{Nb} / \mathrm{Ta}$ ratios of the granodiorite and monzogranite samples ranged from 13.96 to 17.31 (mean value $=15.88$ ) and from 6.52 to 11.08 (mean value $=9.66$ ), respectively. Both of the granitoids are above the average $\mathrm{Nb} / \mathrm{Ta}$ ratios of the lower crust (8.3; [73]) and below the average $\mathrm{Nb} / \mathrm{Ta}$ ratios of mantle-derived rocks (17.4; [54]), further indicating that a certain number of mantle-derived components were involved in the generation of the granodiorite and monzogranite. Isotopically, zircon Hf isotopic analysis is an effective and widely used method to trace the source of magmas [74-76]. All the granodiorite samples had similar zircon Hf isotopic compositions with $\varepsilon \mathrm{Hf}(\mathrm{t})$ values of $0.0-6.2$. In the $\varepsilon \mathrm{Hf}(\mathrm{t})$-age diagram (Figure 7a), they were plot between the depleted mantle and chondrite lines. In addition, the $\mathrm{T}_{\mathrm{DM} 2}$ ages ranged from 1123 to $930 \mathrm{Ma}$ (Supplementary Material Table S5), implying that the granodiorite could be derived from reworked Meso-Neoproterozoic juvenile components. The monzongranite samples had a narrow range of high $\mathrm{I}_{\mathrm{Sr}}$ values $(0.70635-0.70798)$ and low $\varepsilon \mathrm{Nd}(\mathrm{t})$ values $(-5.01$ to -4.11$)$ with the $\mathrm{T}_{\mathrm{DM} 2}$ ages of 1406-1333 Ma, suggesting that the monzongranite may have been sourced from the partial melting of ancient lower crustal material. Notably, the monzongranite samples showed similar Sr-Nd compositions to other Triassic granitoids, plotting in the overlap field of the EKOB continental arc magmas and the EKOB-enriched lithospheric mantle (Figure 7b), which implies that the EKOB enriched lithospheric mantle might have been involved during the generation and/or evolution of the primary magma of the monzongranite.

All the granodiorite and monzongranite samples displayed low Sr (80.79-434.00 ppm), high Y (11.40-23.90 ppm), and high $\mathrm{Yb}$ (1.57-2.01 ppm) values, with low Sr/Y ratios (5.3-37.54), thus belonging to normal arc rocks rather than typical adakitic rocks [60]. The relatively high $\mathrm{Yb}$ concentrations (1.57-2.01 ppm) and relatively flat HREE characteristics (Figure 6a) indicate that partial melting occurred above the stable region of garnet [61]. Therefore, there was no garnet residue in the source. The granodiorite samples show a good linear relation in the Harker diagrams, which implies a strong fractionation of primary magma (Figure $9 \mathrm{~b}-\mathrm{h}$ ). The relative negative correlations between $\mathrm{SiO}_{2}$ and $\mathrm{P}_{2} \mathrm{O}_{5}, \mathrm{CaO}, \mathrm{Al}_{2} \mathrm{O}_{3}$ imply the fractional crystallization of apatite and plagioclase. In the $\mathrm{Rb}-\mathrm{Sr}$ and $(\mathrm{Zr} / \mathrm{Y})-(\mathrm{Hf} / \mathrm{Sm})$ diagrams (Figure 10c,d), the trend of granodiorite samples indicates the crystallization of amphibolite. The crystallization of Fe-Ti oxides and plagioclase can be inferred from the relative negative correlations between $\mathrm{SiO}_{2}$ and $\mathrm{TiO}_{2}, \mathrm{Fe}_{2} \mathrm{O}_{3 \text { total }}$ and $\mathrm{CaO}$, respectively (Figure $9 \mathrm{~b}, \mathrm{c}, \mathrm{f})$. The negative $\mathrm{Eu}$ anomalies $\left(\mathrm{Eu} / \mathrm{Eu}^{*}=0.54-0.64\right.$, Figure $\left.6 \mathrm{a}\right)$ and $\mathrm{Sr}$ negative anomalies of the monzongranite samples also indicate the fractionation crystallization of plagioclase (Figure 6b). The P negative anomalies of monzongranite samples suggest the fractionation crystallization of apatite (Figure $6 \mathrm{~b})$. In the Ba-Sr and $(\mathrm{Zr} / \mathrm{Y})-(\mathrm{Hf} / \mathrm{Sm})$ diagrams, it can be seen that the magma of monzongranite experienced the fractionation-crystallization of K-feldspar and hornblende

In summary, the ore-forming granitoid intrusions were generated by the mixing of crust and mantle-derived magma. The mafic magma was generated by the partial melting of enriched lithospheric mantle and underplated on the bottom of lower crust. As the upwelling enriched lithospheric mantle-derived magma, which rose to the bottom of the lower crust, the partial melting of juvenile (i.e., the Hutouya granodiorite) and ancient mature lower crust (i.e., the Hutouya monzongranite) occurred, which then mixed with mantle-derived magmas. Then, the mixed magmas underwent extensive fractionation-crystallization during the process of rising and emplacement. (Figure 10c,d). 

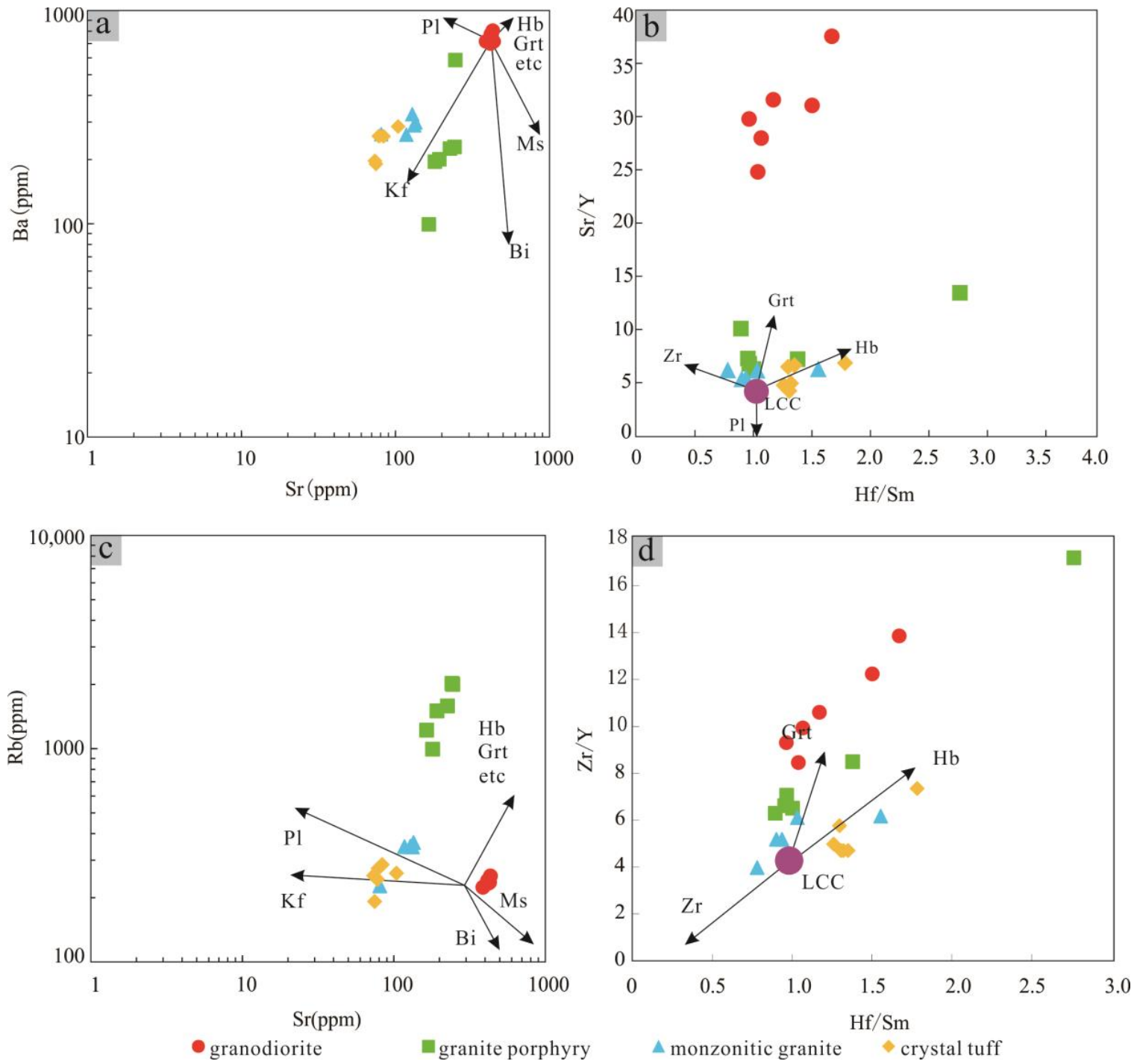

Figure 10. (a) Ba-Sr, (b) (Sr/Y)-(Hf/Sm), (c) Rb-Sr, and (d) $(\mathrm{Zr} / \mathrm{Y})-(\mathrm{Hf} / \mathrm{Sm})$ diagrams for Hutouya deposit granitic rocks and crystal tuff.

\subsubsection{Non-Ore-Related Granite Porphyry and Crystal Tuff}

All the granite porphyry and crystal tuff samples contained high concentrations of $\mathrm{SiO}_{2}$ and $\mathrm{Al}_{2} \mathrm{O}_{3}$ and low concentrations of $\mathrm{MgO}, \mathrm{Cr}, \mathrm{Co}$, and $\mathrm{Ni}$ (Supplementary Material Table S3). All the concentrations mentioned above are in accordance with crust-derived rocks [77]. The low $\mathrm{Nb} / \mathrm{Ta}$ ratios of both the granite porphyry (6.39-8.25) and crystal tuff (6.33-8.17) indicate that the magmas of granite porphyry and crystal tuff probably originated solely from the anatexis of the lower crust. In addition, the low $\mathrm{Mg}^{\#}$ values of the granite porphyry (21-43) further imply that the magma was derived from crustal material. In contrast, the relatively high $\mathrm{Mg}^{\#}$ values of the crystal tuff (51-65) imply that the mantle-derived components were involved in the magma. The high concentrations of Y (12.25-33.33 and 10.90-17.60 of granite porphyry and crystal tuff samples, respectively) and relatively flat HREE pattern (Figure 6a) indicate the presence of residual amphibole [78].

The isotope geochemical data also contribute some proof of the magma source. The non-ore-related granite porphyry samples displayed the following features: their zircon $\varepsilon \mathrm{Hf}(\mathrm{t})$ values and $\mathrm{T}_{\mathrm{DM} 2}$ ages ranged from -5.34 to $-0.85 \mathrm{Ma}$ and 1518 to $1312 \mathrm{Ma}$, respectively, indicating that the primary magma may have been derived from the partial melting of the Mesoproterozoic lower crust (Figure 7a); the nature of the magma source of crystal tuff was revealed through zircon $\mathrm{Sr}-\mathrm{Nd}-\mathrm{Hf}$ isotopic 
compositions; the $\varepsilon \mathrm{Hf}(\mathrm{t})$ values of -4.0 to +0.3 and $\mathrm{T}_{\mathrm{DM} 2}$ ages of $1345-1106 \mathrm{Ma}$ indicate that the primary magma may have originated from the partial melting of the Mesoproterozoic lower crust with a minute quantity of mantle components; and the fairly negative $\varepsilon N d(t)$ values $(-5.43$ to -4.69$)$ and $\mathrm{T}_{\mathrm{DM} 2}$ ages of 1442-1382 Ma also imply that the magma of the crystal tuff was derived from the partial melting of the Mesoproterozoic lower-crustal material.

In the Harker diagrams, the non-ore-related granite porphyry and crystal tuff samples show a slight fractionation of magmas with few relative negative correlations (Figure $9 \mathrm{~b}-\mathrm{h}$ ). Plagioclase crystallization is indicated by their negative Eu anomalies $\left(\mathrm{Eu} / \mathrm{Eu}^{*}=0.34-0.84\right.$ and $0.58-0.63$ for the granite porphyry and crystal tuff samples, respectively; Figure 6a). Amphibolite crystallization is indicated in the $(\mathrm{Hf} / \mathrm{Sm})-(\mathrm{Zr} / \mathrm{Y})$ diagram (Figure 10d). The crystallization and differentiation of $\mathrm{K}$-feldspar is indicated in the Sr-Ba diagram (Figure 10a). The $\mathrm{P}$ and Ti negative anomalies of all the granite porphyry and crystal tuff samples suggest the fractionation-crystallization of apatite and the Fe-Ti oxides.

In summary, non-ore-related granite porphyry was generated by the partial melting of a single ancient mature lower crust, with its primary magma undergoing fractionation-crystallization during the process of rising and emplacement. In contrast, the crystal tuff of the Elashan Formation originated from the mixing of lower crust material and mantle-derived components and also underwent fractionation-crystallization in the process of magma rising. To date, many $\mathrm{Pb}-\mathrm{Ag}$ polymetallic deposits (such as Hariza, Dongshan, Narimalahei, and Zamashan) closely hosted in the continental volcanic rocks of the Elashan Formation have been discovered in the eastern section of the EKOB [29]; therefore, we infer that the acid volcanic rocks of the Elashan Formation, with mixed magma sources, should probably also possess great prospecting potential in the western section of the EKOB.

\subsection{Sources of Ore-Forming Materials}

Sulfur obviously plays an important role in the mineralization and precipitation of metal sulfide deposits, and $\mathrm{S}$ isotopic data provide important information about the sources of ore-forming materials [79,80], as gained from sulfur isotopic characteristics of hydrothermal fluids [81]. The absence of sulfate minerals in all ore belts of the Hutouya deposit shows that the ore-forming hydrothermal fluid is a single component that did not experience complex strong fractionation. For this reason, the values of the $\delta^{34} S_{\text {sulfide }}$ from the sulfide mineral samples can approximately represent the values of $\delta^{34} S_{\text {fluid }}$ in the ore-forming hydrothermal solution $\left(\delta^{34} \mathrm{~S}_{\text {sulfide }} \approx \delta^{34} \mathrm{~S}_{\text {fluid; }}[82,83]\right)$. Overall, our data, together with the previous studies, show that the $\delta^{34} S$ values from the major ore minerals range from $0.6 \%$ to $9.8 \%$ with a mean value of 4.5 (Supplementary Material Table S6). The mean $\delta^{34} \mathrm{~S}$ value is higher than the mantle-derived sulfur $(0 \%$; [84]), meteoritic sulfur (from $-3 \%$ to $+3 \%$; [85]), and the reduced sulfur in sediments $(<0 \%$; [86]), while it is lower than the oceanic carbonate (Cambrian-Triassic $\delta^{34} \mathrm{~S}=15-35 \%$; [87]) and approximately equal to deep magmatic sulfur (from $-5 \%$ to $+5 \%$; [81]), which indicates that the $S$ predominately originated from magmatic sulfur. In addition, the $\delta^{34} \mathrm{~S}$ peaks intervals of sulfide mineral samples from the No. IV ore belt in the north zone $(0.8-5.0 \%$; Supplementary Material Table S6; Figure 11b,c) are similar to ore belts No. II, III and VI in the middle zone, named the "inner contact skarn zones" (0.6-6.8\%; Supplementary Material Table S6; Figure $11 \mathrm{~b}, \mathrm{c}$ ), which are more approximate to the deep magmatic sulfur (from $-5 \%$ to $+5 \%$; [81]), while they are significantly lower than the VII ore belt in the southern zone (6.5-9.8\%o, except for one chalcopyrite sample of $1.6 \%$; Figure $11 \mathrm{a}-\mathrm{c}$ ). In consideration of all the ore bodies bounded by carbonate strata and fracture zones in the No. VII ore belt, named the "outer contact skarn zones", located in the southern part of the Hutouya deposit, the higher $\delta^{34} S$ peak intervals are likely due to the influence of the sulfur from the strata. Therefore, we conclude that concealed ore-forming intrusions and "inner contact skarn zones" probably existed deep within the No. IV, V ore belts of the northern zone within the Hutouya deposit, which shows greater metallogenic potential in the deep zone of the northern part of the Hutouya deposit. 

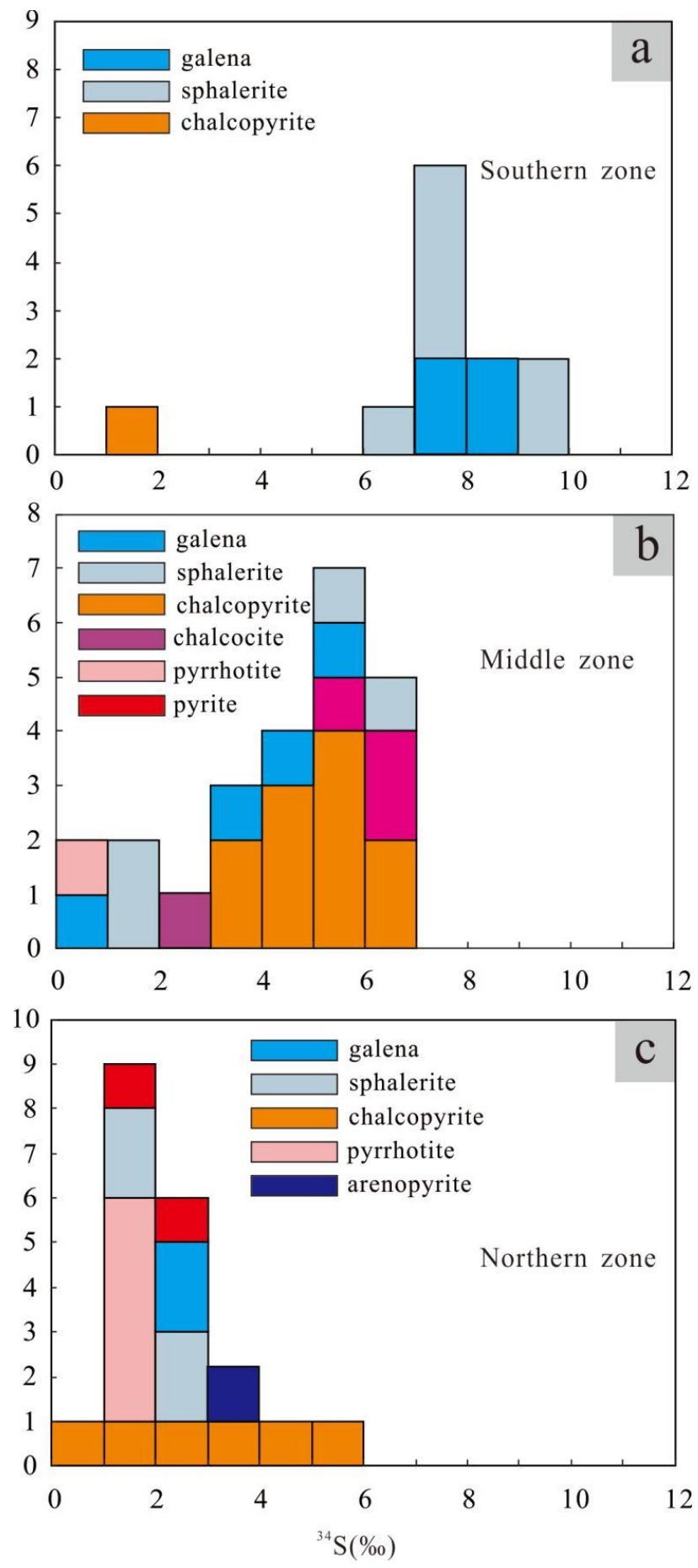

Figure 11. Histogram of sulfur isotopes of the Hutouya deposit. (a) ${ }^{34} \mathrm{~S}$ isotopic compositions of ore minerals for the southern zone within the Hutouya deposit; (b) ${ }^{34} \mathrm{~S}$ isotopic compositions of ore minerals for the middle zone within the Hutouya deposit; (c) ${ }^{34} \mathrm{~S}$ compositions of ore minerals for the northern zone within the Hutouya deposit.

Lead isotope compositions can be used to indicate the evolution of the crust, the source of metallogenic minerals, and the genesis of deposits [88]. According to our data, together with previous studies, all the samples from the Hutouya deposit showed mean $\mu$ values of 9.55 (Supplementary Material Table S7), which is slightly lower than the mean value of the upper crust (9.58; [89]). The mean $\omega$ value (36.34; Supplementary Material Table S7) was between the mean value of the mantle (31.84; [90]) and upper crust (41.86; [90]). The mean Th/U ratio (3.68; Supplementary Material Table S7) was slightly lower 
than the mean Th/ $\mathrm{U}$ ratio of the upper crust in China (3.76; [91]). All these data indicate that the $\mathrm{Pb}$ is likely derived from a mixed source of predominating crust-derived $\mathrm{Pb}$ and little mantle-derived $\mathrm{Pb}$ [92]. To further clarify the source of $\mathrm{Pb}$ in the Hutouya deposit, $\mathrm{Pb}$ isotopic data were also plotted in the $\mathrm{Pb}$-isotope tectonic model diagram (Figure 12a,b) and tectonic environment discrimination diagram (Figure 12c,d). In a $\left({ }^{207} \mathrm{~Pb} /{ }^{204} \mathrm{~Pb}\right)-\left({ }^{206} \mathrm{~Pb} /{ }^{204} \mathrm{~Pb}\right)$ diagram (Figure 11a), the samples were plot mainly between the orogenic and upper crust evolution line with a proximate linear correlation. In a $\left({ }^{208} \mathrm{~Pb} /{ }^{204} \mathrm{~Pb}\right)-\left({ }^{206} \mathrm{~Pb} /{ }^{204} \mathrm{~Pb}\right)$ diagram (Figure $\left.11 \mathrm{~b}\right)$, the samples were plotted mostly on the orogenic evolution line. In tectonic environment discrimination diagrams (Figure 12c,d), the samples mainly fell in the orogen fields. Therefore, we conclude that $\mathrm{Pb}$ in the Hutouya deposit was sourced from the upper crust and the erosion zone of the orogenic belt [93]. In the $\Delta \gamma-\Delta \beta$ diagram, all the samples were mainly plotted in the field of " $3 \mathrm{a}$ ", which indicates that the $\mathrm{Pb}$ was derived from mixed lead from upper crust and mantle subduction (Figure 13). Therefore, the $\mathrm{Pb}$ of all the mineral samples from the Hutouya deposit was derived from a mixed source: the majority from the crust and a small amount from the mantle.
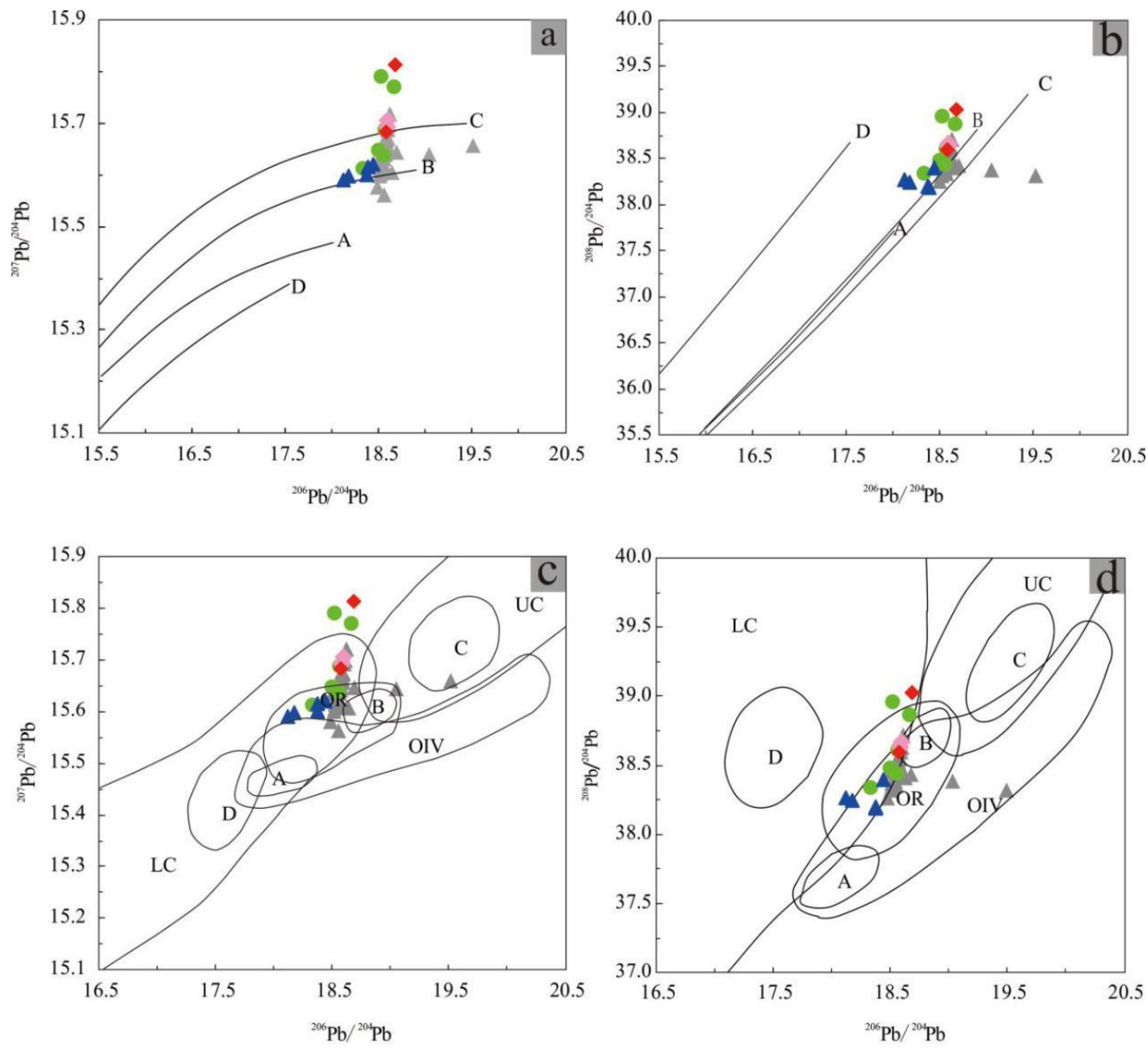

- chalcopyrite $\Delta$ pyrrhotite $\diamond$ galena $\diamond$ sphalerite

Figure 12. (a,b) Pb-isotope tectonic model diagram [89]; and (c,d) tectonic environment discrimination diagram [89] for the Hutouya deposit (LC-lower crust; UC-upper crust; OIV-Ocean Intraplate Volcanism; OR-orogenic belt; A, B, C and D represent the dense domain in each field).

In summary, the sulfur of all the analyzed samples from the northern and middle zone of the Hutouya deposit (including ore belts Nos. II, III, IV, and VI) was derived from deep magmatic sulfur, while the $S$ of all the analyzed samples from the southern zone of the Hutouya deposit (ore belt No. VII) was derived from deep magmatic sulfur and the contribution of strata sulfur. All the ore mineral 
samples showed that $\mathrm{Pb}$ was consistently derived from a mixed source of upper crust and mantle in the Hutouya deposit.

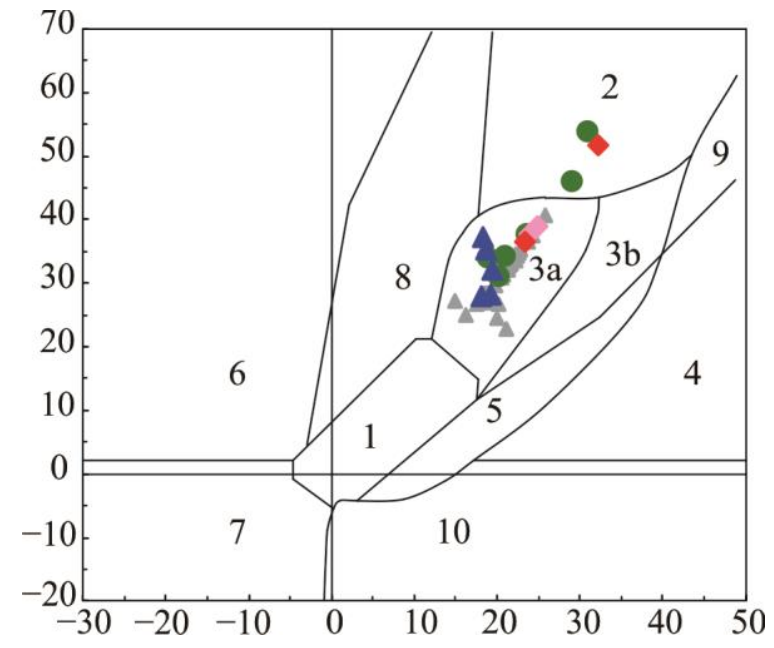

Figure 13. $\Delta \gamma-\Delta \beta$ diagram for genetic classification according to $\mathrm{Pb}$ isotope compositions of the Hutouya deposit ([94]; 1-mantle-derived lead; 2-upper crust lead; 3-mixed lead of upper crust and mantle subduction (3a. magmatism; 3b. sedimentation); 4-chemical sedimentary lead; 5-submarine hydrothermal lead; 6-medium-high grade metamorphism lead; 7-lower crust lead of high grade metamorphism; 8-orogenic belt lead; 9-upper crust lead of ancient shale; 10—retrograde metamorphic lead).

\subsection{Geodynamic Background}

An understanding of the geodynamic background of the EKOB is important for elucidating regional metallogenic processes [95-98]. The EKOB records several different orogenic phases and corresponding orogeneses, in which the orogeny related to the consumption of Paleo-Tethys oceans is an important and complex episode [99,100].

According to data in our study, the Late Triassic granitic rocks and crystal tuff from the Hutouya deposit are calc-alkaline I-type granites. In $\mathrm{Nb}-\mathrm{Y}$, and $\mathrm{Rb}-(\mathrm{Yb}+\mathrm{Ta})$ diagrams (Figure 14), most samples were plotted in the (volcanic arc granites (VAG) + syn-collision granites (Syn-COLG)) and Post-COLG fields, respectively, similar to other Late Triassic high-K calc-alkaline to shoshonite I-type granites in the $\mathrm{EKOB}$, which were supposed to form in a post-collision extensional setting [46,101]. In addition, the presence of Late Triassic A-type granites and adakites suggests that lithosphere delamination occurred and that the EKOB as in post-collision extension [30,102-105].

In the EKOB, a series of large and medium-scale skarn-porphyry Fe- $\mathrm{Cu}(\mathrm{Mo}-\mathrm{Pb}-\mathrm{Zn})$ polymetallic deposits have been generated, and their related ore-forming intrusions were formed during the Late Triassic ([20,106]; Table 1). As previously stated, the Late Triassic post-collision extensional tectonic setting in the EKOB triggered the event of strong mantle-source magma underplating with the emergence of mafic-ultramafic rocks [107-109]. In addition to the mafic-ultramafic rocks, numerous intermediate-felsic rocks derived from a mixing source of mantle and crust also developed (ca. 237-204 Ma; [46]). Therefore, intermediate-felsic rocks were likely generated from the partial melting of a thickened crust heated by strong mantle-derived magma underplating in decompression caused by the post-collision extension during the Late Triassic. This provided abundant ore-forming material as well as a heat source for regional mineralization under the influence of the strong crust-mantle interaction and magmatism in EKOB [23,106], as with the ore-forming granitoid intrusions from the Hutouya deposit in this study. Our results for the magmatism and mineralization ages of the Hutouya polymetallic deposit confirm its association with the Paleo-Tethys evolution of the EKOB. 


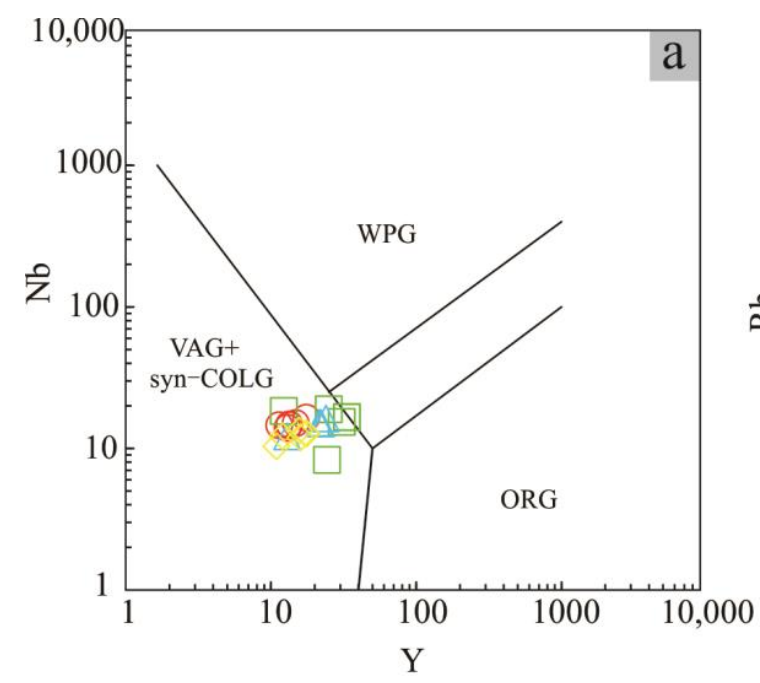

$\bigcirc$ granodiorite $\triangle$ monzonitic granite

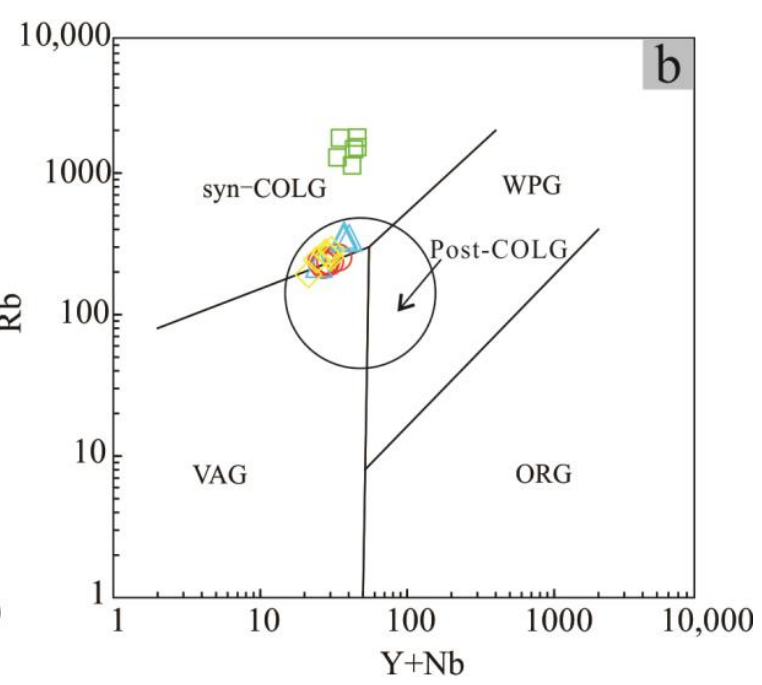

$\square$ granite porphyry $\diamond$ crystal tuff

Figure 14. (a) $\mathrm{Nb}-\mathrm{Y}$ diagram; (b) $\mathrm{Rb}-(\mathrm{Y}+\mathrm{Nb}$ ) diagram for the granitic rocks and crystal tuff of the Hutouya deposit ([58], WPG, within-plate granites; VAG, volcanic arc granites; Syn-COLG, syn-collision granites; Post-COLG, post-collision granites; ORG, ocean ridge granites).

\section{Conclusions}

Our new geochronological and geochemical data for Late Triassic granitoids, crystal tuff, molybdenites, and other ore minerals of the Hutouya $\mathrm{Cu}-\mathrm{Fe}-\mathrm{Pb}-\mathrm{Zn}$ polymetallic deposit allow us to draw the following conclusions:

(1) Zircon LA-ICP-MS U-Pb and molybdenite Re-Os dating reveals that the emplacement of granitoids and mineralization of the Hutouya deposit occurred at ca. $227 \mathrm{Ma}$;

(2) The ore-forming granitoids were generated by the mixing of crust-derived (either juvenile or ancient mature lower crust) and mantle-derived magma. The non-ore-related granite porphyry was generated by the partial melting of a single ancient mature lower crust. The granitic magmas underwent extensive fractional crystallization during the process of rising and emplacement;

(3) The crystal tuff was derived from a mixed magma source of lower crust material and mantle-derived components, and the Elashan Formation probably has great prospecting potential in the western EKOB;

(4) Sulfur in the northern and middle zone of the Hutouya deposit was derived from deep magmatic sulfur, while the $S$ of the southern zone of Hutouya deposit was derived from both deep magmatic sulfur and strata sulfur. All the ore mineral samples show that the $\mathrm{Pb}$ was consistently derived from a mixed source of upper crust and mantle in the Hutouya deposit;

(5) The new data for granitoids and crystal tuff in the the Hutouya area suggest that they were formed at 227-222 Ma in a post-collision extensional geodynamic setting, with the Paleo-Tethys Bayankala Ocean having closed before the Late Triassic.

Supplementary Materials: The following are available online at http://www.mdpi.com/2075-163X/10/12/1136/s1, Table S1: LA-ICP-MS zircon U-Pb data for the granitic rocks and crystal tuff of the Hutouya deposite, Table S2: Re-Os isotopic data for molybdenite of the Hutouya deposit, Table S3: Geochemical compositions of granitic rocks and crystal stuff from the Hutouya deposit (major elements are presented in wt \%; trace elements are presented in ppm), Table S4: Whole-rock Sr-Nd isotopic compositions from the monzonitic granite and crystal stuff of the Hutouya deposit, Table S5: Hf isotopic compositions of zircons from the granoditic rocks and crystal stuff of the Hutouya deposit, Table S6: $\delta^{34} S$ isotopic data for sulfides from the Hutouya deposit, Table S7: Lead isotopic compositions of ore sulfides from the Hutouya deposit. 
Author Contributions: Conceptualization, H.G., F.S., B.L., Y.Q., L.W. and Y.Z.; writing-original draft, H.G.; writing-review end editing, F.S. All authors have read and agreed to the published version of the manuscript.

Funding: This research was funded by the National Natural Science Foundation of China (Grant No. 41402060).

Acknowledgments: We thank the staff of at the State Key Laboratory of Continental Dynamics, Northwest University, Xi'an, China and the State Key Laboratory of Geological Processes and Mineral Resources (LGPMR), China University of Geosciences, Wuhan, China for their advice and assistance during zircon U-Pb dating by LA-ICP-MS. We thank the staff of the National Research Center of Geoanalysis, Chinese Academy of GeoSciences, Beijing, China for their advice and assistance during the Re-Os isotopic analyses. We appreciate Analysis Center of Jilin University, Jilin Province, China, for their assistance in the major and trace element analysis. We thank the staff of the State Key Laboratory of Geological Processes and Mineral Resources (LGPMR), China University of Geosciences, Wuhan, China and the Beijing Yanduzhongshi Testing Technology, Beijing, China for their help with collecting zircon Hf-isotopic data. We are also grateful to the staff of the Analysis and Test Research Center, Geological Research Institute of Nuclear Industry, Beijing for their help with collecting Whole-rock Sr-Nd isotopic data and ore-mineral S-Pb isotopic data.

Conflicts of Interest: The authors declare no conflict of interest.

\section{Appendix A}

\section{Appendix A.1. Zircon U-Pb Dating}

Granitic (JR-N and HT-N) and crystal tuff (DH09-N) samples were selected for zircon U-Pb dating, with zircons being handpicked under a binocular microscope after separation by magnetic and heavy-liquid techniques at the Geological Laboratory of the Regional Geological Survey, Langfang, Hebei Province, China. Zircons were mounted in epoxy resin and polished to expose internal surfaces. Cathodoluminescence was used to image internal structures and to aid in the selection of optimal analysis sites.

Zircons from the Hutouya granodiorite (sample JR-N) were dated at the State Key Laboratory of Continental Dynamics, Northwest University, Xi'an, China, by laser ablation-inductively coupled plasma-mass spectrometry (LA-ICP-MS). The ICP-MS instrument was an Aligent 7500a equipped with a 193 nm ArF-excimer Geolas 200M LA system (MicroLas, Göttingen, Germany), with a laser spot size of $30 \mu \mathrm{m}$, energy of 32-36 mJ and repetition rate of $10 \mathrm{~Hz}$. He was used as the carrier gas. The detailed operating procedures have been described by Yuan et al. (2004) [110]. The US National Institute of Standards and Technology (NIST) standard reference material SRM610 was used to optimize instrument settings. The zircon 91500 was used as an external standard for the corrections of U-Pb isotope fractionation effects. Zircon standard GJ-1 was used as a secondary standard to supervise the deviation of age measurement/calculation. ${ }^{29} \mathrm{Si}$ and NIST 610 were used as an internal standard and external standard for the calibrations of the zircon analyses, respectively. Elemental concentrations and isotopic ratios were calculated using GLITTER program (v4.0, Macquarie University, Sydney, Australia). Ages were calculated using Isoplot 3.0 [111] and common-Pb correction followed the method of Andersen (2002) [112]. All zircon isotope ratios and age uncertainties are quoted at the $1 \delta$ level. Four analyses of the standard GJ-1 gave weighted mean ${ }^{206} \mathrm{~Pb} /{ }^{238} \mathrm{U}$ ages of $610.6 \pm 9.7 \mathrm{Ma}$ $(\mathrm{MSWD}=0.0023, \mathrm{n}=4)$, which agreed well with the recommended ${ }^{206} \mathrm{~Pb} /{ }^{238} \mathrm{U}$ ages of $613 \pm 6 \mathrm{Ma}$ $(2 \delta, \mathrm{n}=20)[113]$.

Zircons from the Hutouya granite porphyry (HT-N) and crystal tuff (DH09-N) were dated at the State Key Laboratory of Geological Processes and Mineral Resources (LGPMR), China University of Geosciences, Wuhan, China, using an Agilent 7500a ICP-MS instrument equipped with a Geolas 2005 LA system. The detailed equipment and operating procedures have been described by Hu et al. [114]. He was used as the carrier gas. Standard zircon 91,500 was used for external calibration of the U-Pb isotope fractionation effects. Zircon standard GJ-1 was used as a secondary standard to supervise the deviation of age measurement/calculation. NIST SRM610 was used for the external calibration of the zircon analyses. Si was used as an internal standard for the external calibration of the zircon analyses. Elemental concentrations and isotopic ratios were calculated using the ICPMS-DataCal program [115,116]. Ages were calculated using Isoplot 3.0 [111]. All zircon isotope ratios and age 
uncertainties are quoted at the $1 \delta$ level. Four analyses of the standard GJ-1 gave weighted mean ${ }^{206} \mathrm{~Pb} /{ }^{238} \mathrm{U}$ ages of $607.9 \pm 5.3 \mathrm{Ma}(\mathrm{MSWD}=0.29, \mathrm{n}=5)$, which agreed well with the recommended ${ }^{206} \mathrm{~Pb} /{ }^{238} \mathrm{U}$ ages of $613 \pm 6 \mathrm{Ma}(2 \delta, \mathrm{n}=20)[113]$.

\section{Appendix A.2. Molybdenite Re-Os Dating}

Re-Os isotopic analyses were performed at the National Research Center of Geoanalysis, Chinese Academy of GeoSciences, Beijing, China. Samples were dissolved in Carius tubes, and Re-Os concentrations and isotopic ratios were determined using a TJA X-series ICP-MS instrument (Thermo Electron Corporation, Waltham, MA, USA). Analytical procedures have been described by $\mathrm{Du}$ et al. (1994, 2004) [117,118] and (Qu, 2003) [119]. Ages were calculated using Isoplot 3.0, with uncertainties given as $2 \sigma$. The standard sample is GBW04436 (JDC) of China national standard.

\section{Appendix A.3. Whole-Rock Major and Trace-Element Analyses}

Whole-rock major and trace-element analyses were conducted at the Analysis Center of Jilin University, Jilin Province, China, using fresh samples without altered or weathered surfaces, crushed, and powdered to $\approx 200$ mesh. Major-element compositions were determined by the ZSX Primus II automatic $X$-ray fluorescence spectrometer with uncertainties of $<3 \%$ according to the national standard of China (GBW 07103 and GBW 07121). Trace-element compositions were determined by Agilent 7500a ICP-MS instrument according to the national standard of China (GBW 07103). Procedures are described by Gao et al. (2002) [120].

\section{Appendix A.4. In Situ Zircon Hf Isotopic Analyses}

Hf isotopic compositions of zircons from granodiorite (JR-N) and crystal tuff (DH09-N) were determined by the Neptune Plus MC-ICP-MS (Thermo Fisher Scientific, Bremen, Germany) in combination with a Geolas 2005 excimer ArF laser ablation system (Lambda Physik, Göttingen, Germany) that was hosted at the state Key Laboratory of Geological Processes and Mineral Resources, China University of Geosciences in Wuhan. A "wire" signal smoothing device was included in this laser ablation system, by which smooth signals were produced even at very low laser repetition rates down to $1 \mathrm{~Hz}$ [121]. The energy density of laser ablation used in this study was $5.3 \mathrm{~J} \mathrm{~cm}^{-2}$. Helium was used as the carrier gas within the ablation cell and was merged with argon (makeup gas) after the ablation cell. As demonstrated by our previous study, for the $193 \mathrm{~nm}$ laser, a consistent two-fold signal enhancement was achieved in helium compared to in argon gas [122]. We used a simple $Y$ junction downstream from the sample cell to add small amounts of nitrogen $\left(4 \mathrm{~mL} \mathrm{~min}{ }^{-1}\right)$ to the argon makeup gas flow [114]. Compared to the standard arrangement, the addition of nitrogen in combination with the use of the newly designed X skimmer cone and Jet sample cone in Neptune Plus improved the signal intensity of $\mathrm{Hf}, \mathrm{Yb}$, and $\mathrm{Lu}$ by a factor of 5.3,4.0, and 2.4, respectively. All data were acquired on zircon in single spot ablation mode at a spot size of $44 \mu \mathrm{m}$ in this study. Each measurement consisted of $20 \mathrm{~s}$ of acquisition of the background signal followed by $50 \mathrm{~s}$ of ablation signal acquisition. Detailed operating conditions for the laser ablation system and the MC-ICP-MS instrument and analytical method were the same as described by $\mathrm{Hu}$ et al. (2012) [123]. The major limitation for accurate in situ zircon Hf isotope determination by LA-MC-ICP-MS is the very large isobaric interference from ${ }^{176} \mathrm{Yb}$ and, to a much lesser extent ${ }^{176} \mathrm{Lu}$ on ${ }^{176} \mathrm{Hf}$. It has been shown that the mass fractionation of $\mathrm{Yb}\left(\beta_{\mathrm{Yb}}\right)$ is not constant over time and that the $\beta_{\mathrm{Yb}}$ that is obtained from the introduction of solutions is unsuitable for in situ zircon measurements [124]. The under or over-estimation of the $\beta_{Y b}$ value would undoubtedly affect the accurate correction of ${ }^{176} \mathrm{Yb}$ and thus the determined ${ }^{176} \mathrm{Hf} /{ }^{177} \mathrm{Hf}$ ratio. We applied the directly obtained $\beta_{\mathrm{Yb}}$ value from the zircon sample itself in real-time in this study. The ${ }^{179} \mathrm{Hf} /{ }^{177} \mathrm{Hf}$ and ${ }^{173} \mathrm{Yb} /{ }^{171} \mathrm{Yb}$ ratios were used to calculate the mass bias of $\mathrm{Hf}\left(\beta_{\mathrm{Hf}}\right)$ and $\mathrm{Yb}\left(\beta_{\mathrm{Yb}}\right)$, which were normalized to ${ }^{179} \mathrm{Hf} /{ }^{177} \mathrm{Hf}=0.7325$ and ${ }^{173} \mathrm{Yb} /{ }^{171} \mathrm{Yb}=1.132685$ [125] using an exponential correction for mass bias. Interference of ${ }^{176} \mathrm{Yb}$ on ${ }^{176} \mathrm{Hf}$ was corrected by measuring the interference-free ${ }^{173} \mathrm{Yb}$ isotope and using ${ }^{176} \mathrm{Yb} /{ }^{173} \mathrm{Yb}=0.79639$ [125] to calculate ${ }^{176} \mathrm{Yb} /{ }^{177} \mathrm{Hf}$. Similarly, the relatively minor 
interference of ${ }^{176} \mathrm{Lu}$ on ${ }^{176} \mathrm{Hf}$ was corrected by measuring the intensity of the interference-free ${ }^{175} \mathrm{Lu}$ isotope and using the recommended ${ }^{176} \mathrm{Lu} /{ }^{175} \mathrm{Lu}=0.02656[126]$ to calculate ${ }^{176} \mathrm{Lu} /{ }^{177} \mathrm{Hf}$. We used the mass bias of $\mathrm{Yb}\left(\beta_{\mathrm{Yb}}\right)$ to calculate the mass fractionation of Lu because of their similar physicochemical properties. Off-line selection and the integration of analyte signals, and mass bias calibrations were performed using ICPMSDataCal [115]. The ${ }^{176} \mathrm{Hf} /{ }^{177} \mathrm{Hf}$ ratios of the standard zircon TEMORA and GJ-1 were $0.282684 \pm 0.000002(1 S D, n=12)$ and $0.282006 \pm 0.000009(1 S D, n=10)$, respectively, similar to the commonly accepted ${ }^{176} \mathrm{Hf} /{ }^{177} \mathrm{Hf}$ ratios of $0.282684 \pm 0.000036$ (2SD) [127] and $0.282000 \pm 0.000005$ (2SD) [128] measured using the solution MC-ICP-MS method.

Hf isotopic compositions of zircons from the granite porphyry (HT-N) were determined at the Beijing Yanduzhongshi Testing Technology, Beijing, China, using a Neptune Plus MC-ICP-MS instrument and NewWave UP213 LA system. Procedures are described by Wu et al. (2006) [129]. The laser spot diameter was $30 \mu \mathrm{m}$, the repetition rate was $8 \mathrm{~Hz}$, the beam fluence was $16 \mathrm{~J} / \mathrm{cm}^{2}$, and the ablation time was $31 \mathrm{~s}$. As the ${ }^{176} \mathrm{Lu} /{ }^{177} \mathrm{Hf}$ ratio in zircons was $<0.002$, the isotopic interference of ${ }^{176} \mathrm{Lu}$ with ${ }^{176} \mathrm{Hf}$ was negligible. The fractionation coefficient of $\mathrm{Yb}$ was based on the mean ${ }^{173} \mathrm{Yb} /{ }^{172} \mathrm{Yb}$ ratio for each spot, and the interference of ${ }^{176} \mathrm{Yb}$ on ${ }^{176} \mathrm{Hf}$ was deducted accordingly. $\mathrm{A}^{173} \mathrm{Yb} /{ }^{172} \mathrm{Yb}$ ratio of 1.35274 was adopted. The ${ }^{176} \mathrm{Hf} /{ }^{177} \mathrm{Hf}$ ratios of the standard zircon PLE was $0.282481 \pm 0.000007$ $(2 \mathrm{SD}, \mathrm{n}=18)$, similar to the commonly accepted ${ }^{176} \mathrm{Hf} /{ }^{177} \mathrm{Hf}$ ratios of $0.282482 \pm 0.000013$ (2SD) measured using the solution MC-ICP-MS method [130].

\section{Appendix A.5. Whole-Rock Sr-Nd Isotopic Analyses}

Whole-rock Sr-Nd isotopic analyses of Hutouya monzonitic granite (DH10-N) and crystal tuff (DH09-N) were undertaken at the Analysis and Test Research Center, Beijing Geological Research Institute of Nuclear Industry, Beijing, using an IsoProbe-T thermal ionization mass spectrometer (TIMS). Sample powders were dissolved in $\mathrm{HF}+\mathrm{HNO}_{3}+\mathrm{HClO}_{4}$, and the solution evaporated to dryness. The residue was dissolved in $0.5 \mathrm{M} \mathrm{HCl}$, and $\mathrm{Sr}$ and $\mathrm{Nd}$ fractions were separated using standard ion-exchange chromatographic techniques with AG50x8 and PTFE-HDEHP resins and HCl eluent. Mass bias corrections were based on ${ }^{86} \mathrm{Sr} /{ }^{88} \mathrm{Sr}$ and ${ }^{146} \mathrm{Nd} /{ }^{144} \mathrm{Nd}$ ratios of 0.1194 and 0.7219 , respectively. Analysis of the $\mathrm{Nd}$ standard JNdi-1 yielded a ${ }^{143} \mathrm{Nd} /{ }^{144} \mathrm{Nd}$ ratio of $0.512109 \pm 0.000003$.

\section{Appendix A.6. S-Pb Isotopic Analyses}

Samples for analysis ( $\approx 5 \mathrm{~g}$ ) were handpicked with $>99 \%$ purity under a binocular microscope and then crushed, screened, cleaned, dried, and ground to $<200$ mesh. S-Pb isotopic analyses were undertaken at the Analysis and Test Research Center, Beijing Geological Research Institute of Nuclear Industry, Beijing. For $\mathrm{S}$ analyses, selected sulfide minerals and $\mathrm{Cu}_{2} \mathrm{O}$ were ground, mixed, and allowed to react to produce $\mathrm{SO}_{2}$, which was collected by freeze-trapping. $\mathrm{S}$ isotopic compositions were determined using an MAT251 gas isotope mass spectrometer, and reported relative to Vienna-Canyon Diablo Troilite (V-CDT) with an analytical precision of better than $\pm 0.2 \%$ Pb isotopic analyses involved an Isotope-T TIMS with uncertainties for ${ }^{208} \mathrm{~Pb} /{ }^{204} \mathrm{~Pb},{ }^{207} \mathrm{~Pb} /{ }^{204} \mathrm{~Pb}$, and ${ }^{206} \mathrm{~Pb} /{ }^{204} \mathrm{~Pb}$ ratios of $<0.05 \%$. The sulfides reference standards are according to the national standard of China (GBW-04414 and GBW-04415). The $\delta^{34}$ S of GBW-04414 and GBW-04415 are $-0.07 \pm 0.13 \%$ and $22.15 \pm 0.14 \%$, respectively, and the uncorrected test data of standard NBS 981 are ${ }^{208} \mathrm{~Pb} / 206 \mathrm{~Pb}=2.164940 \pm 0.000015$, ${ }^{207} \mathrm{~Pb} /{ }^{206} \mathrm{~Pb}=0.914338 \pm 0.000007$, and ${ }^{204} \mathrm{~Pb} /{ }^{206} \mathrm{~Pb}=0.0591107 \pm 0.0000002$.

\section{References}

1. Xia, R.; Wang, C.; Qing, M.; Deng, J.; Carranza, E.J.M.; Li, W.; Guo, X.; Ge, L.; Yu, W. Molybdenite Re-Os, zircon U-Pb dating and $\mathrm{Hf}$ isotopic analysis of the Shuangqing Fe-Pb-Zn-Cu skarn deposit, East Kunlun Mountains, Qinghai Province, China. Ore Geol. Rev. 2015, 66, 114-131. [CrossRef]

2. Gao, Y.B.; Li, W.Y.; Ma, X.G.; Zhang, Z.W.; Tang, Q.Y. Genesis, geochronology and Hf isotopic compositions of the magmatic rocks in Galinge iron deposit, eastern Kunlun. J. Lanzhou Univ. Nat. Sci. 2012, 48, 36-47. (In Chinese with English abstract) [CrossRef] 
3. Tian, C.S.; Feng, C.Y.; Li, J.H.; Cao, D.Z. ${ }^{40}$ Ar- ${ }^{39}$ Ar geochronology of Tawenchahan Fe polymetallic deposit in Qimantag Mountain of Qinghai province and its geological implications. Miner. Depos. 2013, 32, 169-176. (In Chinese with English abstract)

4. Gao, Y.B.; Li, W.Y.; Qian, B.; Li, K.; Li, D.S.; He, S.Y.; Zhang, Z.W.; Zhang, J.W. Geochronology, geochemistry and $\mathrm{Hf}$ isotopic compositions of the granitic rocks related with iron mineralization in Yemaquan deposit, East Kunlun, NW China. Acta Petrol. Sin. 2014, 30, 1647-1665. (In Chinese with English abstract)

5. Yin, S.; Ma, C.; Xu, J. Geochronology, geochemical and Sr-Nd-Hf-Pb isotopic compositions of the granitoids in the Yemaquan orefield, East Kunlun orogenic belt, northern Qinghai-Tibet Plateau: Implications for magmatic fractional crystallization and sub-solidus hydrothermal alteration. Lithos 2017, 294, 339-355. [CrossRef]

6. Feng, C.Y.; Wang, X.P.; Shu, X.F.; Zhang, A.K.; Xiao, Y.; Liu, J.J.; Ma, S.C.; Li, G.C.; Li, D.X. Isotopic chronology of the Hutouya skarn lead-zinc polymetallic ore district in Qimantage area of Qinghai province and its geological significance. J. Jilin Univ. Earth Sci. Ed. 2011, 41, 1806-1817. (In Chinese with English abstract)

7. He, S.Y.; Li, D.S.; Li, L.L.; Qi, L.Y.; He, S.F. Re-Os age of molybdenite from the Yazigou copper (molybdenum) mineralized area in eastern Kunlun of Qinghai Province, and its geological significance. Geotecton. Metallog. 2009, 33, 236-242. (In Chinese with English abstract) [CrossRef]

8. Li, S.J.; Sun, F.Y.; Feng, C.Y.; Liu, Z.H.; Zhao, J.W.; Li, Y.C.; Wang, S. Geochronological study on Yazigou polymetallic deposit in eastern Kunlun, Qinhai Province. Acta Geol. Sin. 2008, 82, 949-955. (In Chinese with English abstract) [CrossRef]

9. Dong, Y.P.; He, D.F.; Sun, S.S.; Liu, X.M.; Zhou, X.; Zhang, F.F.; Yang, Z.; Cheng, B.; Zhao, G.C.; Li, J.H. Subduction and accretionary tectonics of the East Kunlun orogen, western segment of the Central China Orogenic System. Earth Sci. Rev. 2018, 186, 231-261. [CrossRef]

10. Yao, L.; Lü, Z.; Zhao, C.; Pang, Z.; Yu, X.; Yang, T.; Li, Y.; Liu, P.; Zhang, M. Zircon U-Pb geochronological, trace element, and Hf isotopic constraints on the genesis of the Fe and $\mathrm{Cu}$ skarn deposits in the Qiman Tagh area, Qinghai Province, Eastern Kunlun Orogen, China. Ore Geol. Rev. 2017, 91, 387-403. [CrossRef]

11. Xi, R.G.; Xiao, P.X.; Wu, Y.Z.; Dong, Z.C.; Guo, L.; Gao, X.F. The geological significances, composition and age of the monzonitic granite in Kendekeke iron mine. Northwestern Geol. 2010, 43, 195-202. (In Chinese with English abstract)

12. Xiao, Y.; Feng, C.Y.; Liu, J.N.; Yu, M.; Zhou, J.H.; Li, D.X.; Zhao, Y.M. LA-MC-ICP-MS zircon U-Pb dating and sulfur isotope characteristics of Kendekeke Fe-polymetallic deposit, Qinghai Province. Miner. Depos. 2013, 32, 177-186. (In Chinese with English abstract) [CrossRef]

13. She, H.Q.; Zhang, D.Q.; Jiang, X.Y.; Guan, J.; Zhu, H.P.; Feng, C.Y.; Li, D.X. Geological characteristics and genesis of the Ulan Uzhur porphyry copper deposit in Qinghai. Geol. China 2007, 34, 306-314. (In Chinese with English abstract) [CrossRef]

14. Feng, C.Y.; Li, D.S.; Qu, W.J.; Du, A.D.; Wang, S.; Su, S.S.; Jiang, J.H. Re-Os isotopic dating of molybdenite from the Suolajier skarn-type copper-molybdenum deposit of Qimantagh Mountain in Qinghai Province and its geological significance. Rock Miner. Anal. 2009, 28, 223-227. (In Chinese with English abstract) [CrossRef]

15. Wang, S.; Feng, C.Y.; Li, S.J.; Jiang, J.H.; Li, D.S.; Su, S.S. Zircon SHRIMP U-Pb dating of granodiorite in the Kaerqueka polymetallic ore deposit, Qimantagh Mountain, Qinghai Province, and its geological implications. Geol. China 2009, 36, 74-84. (In Chinese with English abstract) [CrossRef]

16. Song, Z.B.; Zhang, Y.L.; Chen, X.Y.; Jiang, L.; Li, D.S.; Shu, X.F.; Li, Y.Z.; Li, J.C.; Kong, H.L. Geochemical characteristics of Harizha granite diorite-porphyry in East Kunlun andtheir geological implications. Miner. Depos. 2013, 32, 157-168. (In Chinese with English abstract)

17. Chen, X.Y.; Zhang, Y.L.; Song, Z.B.; Shu, X.F.; Li, Y.Z. Geological and geochemical characteristics of Qingshuihe Donggou porphyry Cu-Mo deposit in East Kunlun. J. Chin. Univ. Geol. 2013, 19, 357-358. (Suppl. in Chinese)

18. Liu, J.N.; Feng, C.Y.; Qi, F.; Li, G.C.; Ma, S.C.; Xiao, Y. SIMS zircon U-Pb dating and fluid inclusion studies of Xiadeboli Cu-Mo ore district in Dulan County, Qinghai Province, China. Acta Petrol. Sin. 2012, 28, 679-690.

19. Li, B.L.; Zhi, Y.B.; Zhang, L.; Ding, Q.F.; Xu, Q.L.; Zhang, Y.J.; Qian, Y.; Wang, G.; Peng, B.; Ao, C. U-Pb dating, geochemistry, and $\mathrm{Sr}-\mathrm{Nd}$ isotopic composition of a granodiorite porphyry from the Jiadanggen $\mathrm{Cu}-(\mathrm{Mo})$ deposit in the Eastern Kunlun Metallogenic Belt, Qinghai Province, China. Ore Geol. Rev. 2014, 67, 1-10. [CrossRef] 
20. Wang, H.; Feng, C.Y.; Li, D.X.; Li, C.; Ding, T.Z.; Liao, F.Z. Geology, geochronology and geochemistry of the Saishitang $\mathrm{Cu}$ deposit, East Kunlun Mountains, NW China: Constraints on ore genesis and tectonic setting. Ore Geol. Rev. 2016, 72, 43-59. [CrossRef]

21. Liu, J.P.; Lai, J.Q.; Gu, X.P.; Wang, X.J.; Mao, Y.; Song, W.B. Geochemistry and zircon LA-ICPMS U-Pb geochronology of intrusive body in Saishitang copper deposit, Qinghai Province, China. Chin. J. Nonferr. Met. 2012, 22, 622-632. (In Chinese with English abstract)

22. Yan, Y.F.; Yang, X.S.; Chen, F.B.; Zhang, J.M.; Xu, H.Q.; Zhang, L. Molybdenum containing granites in Lalingzaohuo of the East Kunlun. China Sci. Technol. Inf. 2012, 37-39. (In Chinese with English abstract) [CrossRef]

23. Feng, C.Y.; Li, D.S.; Wu, Z.S.; Li, H.J.; Zhang, Z.Y.; Zhang, A.K.; Shu, X.F.; Su, S.S. Major types, time-space distribution and metallogeneses of polymetallic deposits in the Qimantage metallogenic belt, eastern Kunlun area. Northwestern Geol. 2010, 43, 10-17. (In Chinese with English abstract) [CrossRef]

24. Zhang, A.K.; Liu, G.L.; Feng, C.Y.; Mo, X.X.; Yang, L.C.; Liu, Y.L.; He, S.Y.; Ma, Y.S. Geochemical characteristics and ore-controlling factors of Hutouya polymetallic deposit, Qinghai Province. Miner. Depos. 2013, 32, 94-108. (In Chinese with English abstract) [CrossRef]

25. Lei, Y.B.; Lai, J.Q.; Wang, X.J.; Su, S.S.; Wang, S.L.; Tao, S.L. Origin and evolution of ore-forming material of Hutouya polymetallic deposit. Chin. J. Nonferr. Met. 2014, 24, 2117-2128.

26. Yao, L.; Lü, Z.; Yu, X.; Pang, Z.; Cai, Y.; Liu, P.; Wang, F. Petrogenesis, geochemistry and zircon U-Pb age of the granite from No. VI section of Hutouya deposit, Qimantag area, Qinghai province, and its geological significance. J. Jilin Univ. Earth Sci. Ed. 2015, 45, 743-758. (In Chinese with English abstract) [CrossRef]

27. Zhang, X.F.; Li, Z.M.; Jia, Q.Z.; Song, Z.B.; Chen, X.Y.; Zhang, Y.L.; Li, D.S.; Shu, X.F. Geochronology, geochemistry and geological significance of granite porphyry in Hutouya polymetallic deposit, Qimantage area, Qinghai province. J. Jilin Univ. Earth Sci. Ed. 2016, 46, 749-765. (In Chinese with English abstract) [CrossRef]

28. Ma, Z.Y.; Ma, C.X.; Ye, Z.F.; Hao, Y.; Ma, F.S.; Tong, M.H.; Zhou, L.Q. Rock and geochemical characteristics of late Triassic continental volcanic rock of Elashan group in the East Kunlun. J. Qinghai Univ. 2016, 34, 31-37.

29. Chen, N.; Sun, M.; Wang, Q.; Zhao, G.; Chen, Q.; Shu, G. EMP chemical ages of monazites from Central Zone of the eastern Kunlun Orogen: Records of multi-tectonometamorphic events. Chin. Sci. Bull. 2007, 52, 2252-2263. [CrossRef]

30. Ding, Q.F.; Jiang, S.Y.; Sun, F.Y. Zircon U-Pb geochronology, geochemical and Sr-Nd-Hf isotopic compositions of the Triassic granite and diorite dikes from the Wulonggou mining area in the Eastern Kunlun Orogen, NW China: Petrogenesis and tectonic implications. Lithos 2014, 205, 266-283. [CrossRef]

31. Jiang, C.F.; Yang, J.S.; Feng, B.G.; Zhu, Z.Z.; Zhao, M.; Chai, Y.C.; Shi, X.D.; Wang, H.D.; Hu, J.Q. Opening-Closing Tectonics of Kunlun Mountains; Geological Publishing House: Beijing, China, 1992; pp. 1-217.

32. Sun, F.Y.; Li, B.L.; Ding, Q.F.; Zhao, J.W.; Pan, T.; Yu, X.F.; Wang, L.; Chen, G.J.; Ding, Z.J. Research on the key problems of ore prospecting in the Eastern Kunlun metallogenic belt. Geological survey Institute of Jilin University, Changchun. Tectonophysics 2009, 43, 7-22. (In Chinese)

33. Zhang, J.X.; Meng, F.C.; Wan, Y.S.; Yang, J.S.; Dong, G.A. Early Paleozoic tecto-thermal event of Jinshuikou Group on the sourthern margin of Qaidam: Zircon U-Pb SHRIMP age evidence. Geol. Bull. China 2003, 22, 397-404.

34. Bian, Q.T.; Li, D.H.; Pospelov, I.; Yin, L.M.; Li, H.S.; Zhao, D.S.; Chang, C.F.; Luo, X.Q.; Gao, S.L.; Astrakhantsev, O. Age, geochemistry and tectonic setting of Buqingshan ophiolites, north Qinghai-Tibet Plateau, China. J. Asian Earth Sci. 2004, 23, 577-596. [CrossRef]

35. Chen, X.; Gehrels, G.; Yin, A.; Zhou, Q.; Huang, P. Geochemical and Nd-Sr-Pb-O isotopic constrains on Permo-Triassic magmatism in eastern Qaidam Basin, northern Qinghai-Tibetan plateau: Implications for the evolution of the Paleo-Tethys. J. Asian Earth Sci. 2015, 114, 674-692. [CrossRef]

36. Roger, F.; Arnaud, N.; Gilder, S.; Tapponnier, P.; Jolivet, M.; Brunel, M.; Malavieille, J.; Xu, Z.; Yang, J. Geochronological and geochemical constraints on Mesozoic suturing in east central Tibet. Tectonics 2003, 22, 1037. [CrossRef]

37. Yang, J.S.; Robinson, P.; Jiang, C.F.; Xu, Z.Q. Ophiolites of the Kunlun Mountains, China and their tectonic implications. Tectonophysics 1996, 258, 215-231. [CrossRef] 
38. Liu, Z.Q.; Pei, X.Z.; Li, R.B.; Li, Z.C.; Zhang, X.F.; Liu, Z.G.; Chen, G.H.; Chen, Y.X.; Ding, S.P.; Guo, J.F. LA-ICP-MS zircon U-Pb geochronology of the two suites of ophiolites at the Buqingshan area of the A'nyemaqen orogenic belt in the southern margin of east Kunlun and its tectonic implication. Acta Geol. Sin. 2011, 85, 185-194. (In Chinese with English abstract)

39. Yang, J.S.; Shi, R.D.; Wu, C.L.; Wang, X.B.; Robinson, P. Dur'ngoi ophiolite in East Kunlun, Northeast Tibetan plateau: Evidence for paleo-Tethyan suture in Northwest China. J. Earth Sci. 2009, 20, 303-331. [CrossRef]

40. Yang, J.S.; Wang, X.B.; Shi, R.D.; Xu, Z.Q.; Wu, C.L. The Dur'ngoi ophiolite in East Kunlun, northern Qinghai-Tibet Plateau: A fragment of Paleo-Tethyan oceanic crust. Geol. China 2004, 31, 225-239. (In Chinese with English abstract)

41. Xia, R.; Wang, C.; Qing, M.; Li, W.; Carranza, E.J.M.; Guo, X.; Ge, L.; Zeng, G. Zircon U-Pb dating, geochemistry and $\mathrm{Sr}-\mathrm{Nd}-\mathrm{Pb}-\mathrm{Hf}-\mathrm{O}$ isotopes for the Nan'getan granodiorites and mafic microgranular enclaves in the East Kunlun Orogen: Record of closure of the Paleo-Tethys. Lithos 2015, 234, 47-60. [CrossRef]

42. Zhang, J.Y.; Ma, C.Q.; Xiong, F.H.; Liu, B. Petrogenesis and tectonic significance of the Late Permian-Middle Triassic calc-alkaline granites in the Balong region, eastern Kunlun Orogen, China. Geol. Mag. 2012, 149, 892-908. [CrossRef]

43. Li, R.B.; Pei, X.Z.; Li, Z.C.; Liu, Z.Q.; Chen, G.C.; Chen, Y.X.; Wei, F.H.; Gao, J.M.; Liu, C.J.; Pei, L. Geological characteristics of late Palaeozoic-Mesozoic unconformities and their response to some significant tectonic events in eastern part of Eastern Kunlun. Earth Sci. Front. 2012, 19, 244-254. (In Chinese with English abstract) [CrossRef]

44. Li, R.B.; Pei, X.Z.; Li, Z.C.; Pei, L.; Chen, Y.X.; Liu, C.J.; Chen, G.C.; Liu, T.J. The depositional sequence and prototype basin for Lower Triassic Hongshuichuan Formation in the eastern segment of East Kunlun Mountains. Geol. Bull. China 2015, 34, 2302-2314. (In Chinese with English abstract)

45. Wang, G. Metallogenesis of Nickel Deposite in East Kunlun Orogenic Belt, Qinghai Province. Ph.D. Dissertation, Jilin University, Changchun, China, 2014.

46. Feng, C.Y.; Wang, S.; Li, G.C.; Ma, S.C.; Li, D.S. Middle to Late Triassic granitoids in the Qimantage area, Qinghai Province, China: Chronology, geochemistry and metallogenic significances. Acta Petrol. Sin. 2012, 28, 665-678. (In Chinese with English abstract)

47. Corfu, F.; Hanchar, J.M.; Hoskin, P.W.O.; Kinny, P.D. Atlas of zircon textures. Rev. Mineral. Geochem. 2003, 53, 469-500. [CrossRef]

48. Selby, D.; Creaser, R.A. Macroscale NTIMS and microscale LA-MC-ICP-MS Re-Os isotopic analysis of molybdenite: Testing spatial restrictions for reliable Re-Os age determinations, and implications for the decoupling of Re and Os within molybdenite. Geochim. Cosmochim. Acta 2004, 68, 3897-3908. [CrossRef]

49. Stein, H.J.; Markey, R.J.; Morgan, J.W.; Du, A.; Sun, Y. Highly precise and accurate Re-Os ages for molybdenite from the East Qinling molybdenite belt, Shanxi Province, China. Econ. Geol. 1997, 92, 827-835. [CrossRef]

50. Stein, H.J.; Markey, R.J.; Morgan, J.W.; Hannah, J.L.; Schersten, A. The remarkable Re-Os chronometer in molybdenite: How and why it works. Terra Nova 2001, 13, 479-486. [CrossRef]

51. Peccerillo, A.; Taylor, S.R. Geochemistry of eocene calc-alkaline volcanic rocks from the Kastamonu area, Northern Turkey. Contrib. Mineral. Petrol. 1976, 63-81. [CrossRef]

52. Maniar, P.D.; Piccoli, P.M. Tectonic discrimination of granitoids. Geol. Soc. Am. Bull. 1989, 101, 635-643. [CrossRef]

53. Boynton, W.V. Chapter 3-cosmochemistry of the rare earth elements: Meteorite studies. Dev. Geochem. 1984, 2, 63-114.

54. Sun, S.S.; McDonough, W.F. Chemical and isotopic systematics od oceanic basalts: Implications for mantle composition and processes. Geol. Soc. Lond. Spec. Publ. 1989, 42, 313-345. [CrossRef]

55. Li, R.B.; Pei, X.Z.; Pei, L.; Pei, L.; Li, Z.C.; Chen, G.C.; Chen, Y.X.; Liu, C.J.; Wang, M. The Early Triassic Andean-type Halagatu granitoids pluton in the East Kunlun orogen, northern Tibet Plateau: Response to the northward subduction of the Paleo-Tethys Ocean. Gondwana Res. 2018, 62, 212-226. (In Chinese with English abstract) [CrossRef]

56. Harris, N. Radiogenic isotopes and the interpretation of granitic rocks. Episodes 1996, 19, 103-107. [CrossRef]

57. Selby, D.; Greaser, R.A. Re-Os geochronology and systematics in molybdenite from the Endako porphyry molybdenum deposit, British Columbia, Canada. Econ. Geol. 2001, 96, 197-204. [CrossRef]

58. Pearce, J.A.; Harris, N.B.; Tindle, A.G. Trace element discrimination diagrams for the tectonic interpretation of granitic rocks. J. Petrol. 1984, 25, 956-983. [CrossRef] 
59. Chappell, B.W.; White, A.J.R. Two contrasting granite types: 25 years later. Aust. J. Earth Sci. 2001, 48, 489-499. [CrossRef]

60. Whalen, J.B.; Currie, K.L.; Chappell, B.W. A-type granites: Geochemical characteristics, discrimination and petrogenesis. Contrib. Mineral. Petrol. 1987, 95, 407-419. [CrossRef]

61. Chappel, B.W.; White, A.J.R. Two contrasting granite types. Pac. Geol. 1974, 8, 173-174.

62. Chappell, B.W. Aluminium saturation in I- and S-type granites and the characterization of fractionated haplogranites. Lithos 1999, 46, 535-551. [CrossRef]

63. Pichavant, M.; Montel, J.M.; Richard, L.R. Apatite solubility in peraluminous liquids: Experimental data and an extension of the Harrison-Watson model. Geochim. Cosmochim. Acta 1992, 56, 3855-3861. [CrossRef]

64. Wu, F.Y.; Jahn, B.M.; Wilde, S.A.; Lo, C.H.; Yui, T.F.; Lin, Q.; Ge, W.C.; Sun, D.Y. Highly fractionated I-type granites in NE China (I): Geochronology and petrogenesis. Lithos 2003, 66, 241-273. [CrossRef]

65. Ghani, A.A.; Searle, M.P.; Robb, L.; Chung, S.L. Transitional I S type characteristic in the Main Range Granite, Peninsular Malaysia. J. Asian Earth Sci. 2013, 76, 225-240. [CrossRef]

66. Singh, J.; Johannes, W. Dehydration melting of tonalites. Part I. Beginning of melting. Contrib. Mineral. Petrol. 1996, 125, 16-25. [CrossRef]

67. White, A.J.R.; Chappell, B.W. Ultrametamorphism and granitoid genesis. Tectonophysics 1977, 43, 7-22. [CrossRef]

68. Karsli, O.; Dokuz, A.; Uysal, I.; Aydin, F.; Chen, B.; Kandemir, R.; Wijbrans, J. Relative contributions of crust and mantle to generation of Campanian high-K calc-alkaline I-type granitoids in a subduction setting, with special reference to the Harsit Pluton, Eastern Turkey. Contrib. Mineral. Petrol. 2010, 160, 467-487. [CrossRef]

69. Barbarin, B. A review of the relationships between granitoid types, their origins and their geodynamic environments. Lithos 1999, 46, 605-626. [CrossRef]

70. Nabelek, P.I.; Liu, M.; Sirbescu, M.L. Thermo-rheological, shear heating model for leucogranite generation, metamorphism, and deformation during the Proterozoic Trans-Hudson orogeny, Black Hills, South Dakota. Tectonophysics 2001, 342, 371-388. [CrossRef]

71. Rapp, R.P.; Watson, E.B. Dehydration melting of metabasalt at 8-32 kbar: Implications for continental growth and crust-mantle recycling. J. Petrol. 1995, 36, 891-931. [CrossRef]

72. Smithies, R.H.; Champion, D.C. The Archaean high-Mg diorite suite: Links to Tonalite-trondhjemitegranodiorite magmatism and implications for Early Archaean crustal growth. J. Petrol. 2000, 41, 1653-1671. [CrossRef]

73. Rudnick, R.L.; Gao, S. Composition of the continental crust. In Treatise on Geochemistry; Heinrich, D.H., Karl, K.T., Eds.; Pergamon: Oxford, UK, 2003; pp. 1-64.

74. Kemp, A.I.S.; Hawkesworth, C.J.; Foster, G.L.; Paterson, B.; Woodhead, J.D.; Hergt, J.M.; Gray, C.M.; Whitehouse, M.J. Magmatic and crustal differentiation history of granitic rocks from Hf-O isotopes in zircon. Science 2007, 315, 980-983. [CrossRef] [PubMed]

75. Santosh, M.; Yang, Q.Y.; Shaji, E.; Tsunogae, T.; RamMohan, M.; Satyanarayanan, M. An exotic Mesoarchean microcontinent: The Coorg Block, southern India. Gondwana Res. 2015, 27, 165-195. [CrossRef]

76. Wu, F.Y.; Li, X.H.; Zheng, Y.F.; Gao, S. Lu-Hf isotopic systematics and their applications in petrology. Acta Petrol. Sin. 2007, 23, 185-220. (In Chinese with English abstract) [CrossRef]

77. Chappell, B.W.; White, A.J.R. I- and S-type granites in the Lachlan Fold Belt. Earth Environ. Sci. Trans. R. Soc. Edinb. 1992, 83, 1-26. [CrossRef]

78. Xie, Y.C.; Lu, J.J.; Ma, D.S.; Zhang, R.Q.; Gao, J.F.; Yao, Y. Origin of granodiorite porphyry and mafic microgranular enclave in the Baoshan $\mathrm{Pb}-\mathrm{Zn}$ polymetallic deposit, southern Hunan Province: Zircon U-Pb chronological, geochemical and Sr-Nd-Hf isotopic constraints. Acta Petrol. Sin. 2013, 29, 4186-4214. (In Chinese with English abstract)

79. Ohmoto, H. Stable isotope geochemistry of ore deposits. Rev. Miner. Geochem. 1986, 16, 491-559.

80. Rye, R.O.; Ohmoto, H. Sulfur and carbon isotopes and ore genesis: A review. Econ. Geol. 1974, 69, 826-842. [CrossRef]

81. Ohmoto, H. Isotopes of sulfur and carbon. In Geochemistry of Hydrothermal Ore Deposits; Barnes, H.L., Ed.; Wiley: New York, NY, USA, 1979; pp. 509-567.

82. Kelly, W.C.; Rye, R.O. Geologic, fluid inclusion, and stable isotope studies of the tin-tungsten deposits of Panasqueira, Portugal. Econ. Geol. 1979, 74, 1721-1822. [CrossRef] 
83. Ohmoto, H. Systematics of sulfur and carbon isotopes in hydrothermal ore deposits. Econ. Geol. 1972, 67, 551-578. [CrossRef]

84. Chaussidon, M.; Albarède, F.; Sheppard, S.M.F. Sulphur isotope variations in the mantle from ion microprobe analyses of micro-sulphide inclusions. Earth Planet. Sci. Lett. 1989, 92, 144-156. [CrossRef]

85. Chaussidon, M.; Lorand, J.P. Sulphur isotope composition of orogenic spinel lherzolite massifs from Ariege (North-Eastern Pyrenees, France): An ion microprobe study. Geochim. Cosmochim. Acta 1990, 54, 2835-2846. [CrossRef]

86. Rollinson, H.R. Using Geochemical Data: Evaluation, Presentation, Interpretation; Longman Scientific and Technical Press: London, UK, 1993; pp. 306-308.

87. Claypool, G.E.; Holser, W.T.; Kaplan, I.R.; Sakai, H.; Zak, I. The age curves of sulfur and oxygen isotopes in marine sulfate and their mutual interpretation. Chem. Geol. 1980, 28, 199-260. [CrossRef]

88. Chiaraida, M.; Fontbote, L.; Paladines, A. Metal sources in mineral deposits and crustal rocks of Ecuador: A lead isotope synthesis. Econ. Geol. 2004, 99, 1085-1106. [CrossRef]

89. Zartman, R.E.; Doe, B.R. Plumbotectonics: The model. Tectonophysics 1981, 175, 135-162. [CrossRef]

90. Doe, B.R.; Zartman, R.E. Plumbotectonics: The phanerozoic. In Geochemistry of Hydrothermal Ore Deposits, 2nd ed.; Barnes, H.L., Ed.; John Wiley and Sons: New York, NY, USA, 1979; pp. 22-70.

91. Li, L.; Zheng, Y.F.; Zhou, J.B. Dynamic model for pb isotope evolution in the continental crust of china. Acta Petrol. Sin. 2001, 17, 61-68. (In Chinese with English abstract) [CrossRef]

92. He, P.; Guo, S.; Zhang, K.; Zhang, T.F.; Su, H.; Ma, Y.X. The sources of ore-forming materials and genesis of the Changtuxili Ag-Pb-Zn-Mn polymetallic deposit in the middle-southern segment of Da Hinggan Mountains: Contrains from S-Pb-C-O isotope geochemistry. Acta Geol. Sin. 2019, 93, 2037-2054. (In Chinese with English abstract)

93. Li, Z.D.; Xue, C.J.; Dong, X.F.; Liu, Z.R.; Zhong, T.Z.; Qi, S.J. Ore geology, S- and Pb- isotopic compositions of the Wulagen Zn-Pb deposit, Wuqia country, Xinjiang. Earth Sci. Front. 2013, 20, 40-54. (In Chinese with English abstract)

94. Zhu, B.Q.; Li, X.H.; Dai, T.M.; Chen, Y.W.; Fan, S.K.; Gui, X.T.; Wang, H.F. The Theory and Application of Isotopic System in Earth Science, 1st ed.; Science Press: Beijing, China, 1998; pp. 1-330. (In Chinese with English abstract)

95. Li, J.X.; Qin, K.Z.; Li, G.M.; Xiao, B.; Chen, L.; Zhao, J.X. Post-collisional ore-bearing adakitic porphyries from Gangdese porphyry copper belt, southern Tibet: Melting of thickened juvenile arc lower crust. Lithos 2011, 126, 265-277. [CrossRef]

96. Li, Z.Z.; Qin, K.Z.; Li, G.M.; Ishihara, S.; Jin, L.Y.; Song, G.X.; Meng, Z.J. Formation of the giant Chalukou porphyry Mo deposit in northern Great Xing'an Range, NE China: Partial melting of the juvenile lower crust in intra-plate extensional environment. Lithos 2014, 202, 138-156. [CrossRef]

97. Wu, Y.S.; Chen, Y.J.; Zhou, K.F. Mo deposits in Northwest China: Geology, geochemistry, geochronology and tectonic setting. Ore Geol. Rev. 2017, 81, 641-671. [CrossRef]

98. Zhou, L.L.; Zeng, Q.D.; Liu, J.M.; Zhang, Z.L.; Duan, X.X. What triggers fertile porphyritic Mo magmas in subduction setting: A case study from the giant Daheishan Mo deposit, NE China. Lithos 2018, 31, 212-231. [CrossRef]

99. Wang, G.C.; Wei, Q.R.; Jia, C.X.; Zhang, K.X.; Li, D.W.; Zhu, Y.H.; Xiang, S.Y. Some ideas of Precambrian geology in the East Kunlun, China. Geol. Bull. China 2007, 26, 929-937. (In Chinese with English abstract)

100. Xu, Z.Q.; Yang, J.S.; Li, H.Q.; Wang, R.R.; Cai, Z.H. Indosinian collision-orogenicsystem of Chinese continent and its orogenic mechanism. Acta Petrol. Sin. 2012, 28, 1697-1709. (In Chinese with English abstract) [CrossRef]

101. Zhang, M.Y.; Feng, C.Y.; Wang, H.; LI, D.X.; Qu, H.Y.; Liu, J.N.; Zhou, J.H. Petrogenesis and tectonic implications of the Late Triassic syenogranite in Qimantag area, East Kunlun Moutains. Acta Petrol. Sin. Mineral. 2018, 37, 197-210. (In Chinese with English abstract)

102. Chen, G.H.; Pei, X.Z.; Li, R.B.; Li, Z.C.; Liu, C.J. Late Triassic magma mixing in the East Kunlun orogenic belt: A case study of Helegang Xilikete granodiorites. Geol. China 2013, 40, 1044-1065. (In Chinese with English abstract)

103. Hu, Y.; Niu, Y.L.; Li, J.Y.; Ye, L.; Kong, J.J.; Chen, S.; Zhang, Y.; Zhang, G.R. Petrogenesis and tectonic significance of the late Triassic mafic dikes and felsic volcanic rocks in the East Kunlun Orogenic Belt, Northern Tibet Plateau. Lithos 2016, 254, 205-222. [CrossRef] 
104. Xia, R.; Wang, C.; Deng, J.; Carranza, E.J.M.; Li, W.; Qing, M. Crustal t hickening prior to 220Ma in the East Kunlun Orogenic Belt: Insights from the Late Triassic granitoids in the Xiao-Nuomuhong pluton. J. Asian Earth Sci. 2014, 93, 193-210. [CrossRef]

105. Xiong, F.H.; Ma, C.Q.; Zhang, J.Y.; Liu, B.; Jiang, H.A. Reworking of old continental lithosphere: An important crustal evolution mechanism in orogenic belts, as evidenced by Triassic I-type granitoids in the East Kunlun orogen, Northern Tibetan Plateau. J. Geol. Soc. 2014, 171, 847-863. [CrossRef]

106. Ma, C.Q.; Xiong, F.H.; Yin, S.; Wang, L.X.; Gao, K. Intensity and cyclicity of orogenic magmatism: An example from a Paleo-Tethyan granitoid batholith, Eastern Kunlun, northern Qinghai-Tibetan Plateau. Acta Petrol. Sin. 2015, 31, 3555-3568.

107. Ao, C.; Sun, F.Y.; Li, B.L.; Wang, G.; Li, L.; Li, S.J.; Zhao, J.W. U-Pb dating, geochemistry and tectonic implications of Xiaojianshan gabbro in Qimantage Mountain, Eastern Kunlun orogenic belt. Geotecton. Metallog. 2015, 39, 1176-1184. (In Chinese with English abstract) [CrossRef]

108. Luo, Z.H.; Ke, S.; Cao, Y.Q.; Deng, J.F.; Chen, H.W. Late Indosinian mantle-derived magmatism in the East Kunlun. Geol. Bull. China 2002, 292-297. (In Chinese with English abstract) [CrossRef]

109. Zhao, C.S. Gold, Silver Metallogeny in Eastern Kunlun Orogenic Belt, Qinghai Province. Ph.D. Dissertation, Jilin University, Changchun, China, 2004.

110. Yuan, H.L.; Gao, S.; Liu, X.M.; Li, H.; Günther, D.; Wu, F.Y. Accurate U-Pb age and trace element determinations of zircon by laser ablation-inductively coupled plasma-mass spectrometry. Geostand. Geoanal. Res. 2004, 28, 353-370. [CrossRef]

111. Ludwig, K. User's Manual for Isoplot 3.00: A Geochronology Toolkit for Microsoft Excel; Berkeley Geochronological Center Special Publication: Berkeley, CA, USA, 2003; Volume 70.

112. Andersen, T. Correction of common lead in $\mathrm{U}-\mathrm{Pb}$ analyses that do not report ${ }^{204} \mathrm{~Pb}$. Chem. Geol. 2002, 192, 59-79. [CrossRef]

113. Xie, L.W.; Zhang, Y.B.; Zhang, H.H.; Sun, J.F.; Wu, F.Y. In situ simultaneous determination of trace elements, $\mathrm{U}-\mathrm{Pb}$ and $\mathrm{Lu}-\mathrm{Hf}$ isotopes in zircon and baddeleyite. Chin. Sci. Bull. 2008, 53, 1565-1573. [CrossRef]

114. Hu, Z.C.; Gao, S.; Liu, Y.S.; Hu, S.H.; Chen, H.H.; Yuan, H.L. Signal enhancement in laser ablation ICP-MS by addition of nitrogen in the central channel gas. J. Anal. At. Spectrom. 2008, 23, 1093-1101. [CrossRef]

115. Liu, Y.S.; Gao, S.; Hu, Z.C.; Gao, C.G.; Zong, K.Q.; Wang, D.B. Continental and oceanic crust recycling-induced melt-peridotite interactions in the Trans-North China Orogen: U-Pb dating, Hf isotopes and trace elements in zircons from mantle xenoliths. J. Petrol. 2010, 51, 537-571. [CrossRef]

116. Liu, Y.S.; Hu, Z.C.; Gao, S.; Günther, D.; Xu, J.; Gao, C.G.; Chen, H.H. In situ analysis of major and trace elements of anhydrous minerals by LA-ICP-MS without applying an internal standard. Chem. Geol. 2008, 257, 34-43. [CrossRef]

117. Du, A.D.; He, H.L.; Yin, W.N.; Zhou, X.Q.; Sun, Y.L.; Sun, D.Z.; Chen, S.Z.; Qu, W.J. The study on the analytical methods of Re-Os age for molybdenites. Acta Geol. Sin. 1994, 68, 339-347.

118. Du, A.D.; Wu, S.Q.; Sun, D.Z.; Wang, S.X.; Qu, W.J.; Markey, R.; Stain, H.; Morgan, J.; Malinovskiy, D. Preparation and certification of Re-Os dating reference materials: Molybdenites HLP and JDC. Geostand. Geoanal. Res. 2004, 28, 41-52. [CrossRef]

119. Qu, W.J.; Du, A.D. Highly precise Re-Os dating of molybdenite by ICP-MS with Carius tube sample digestion. Rock Miner. Anal. 2003, 22, 254-257. (In Chinese with English abstract)

120. Gao, S.; Liu, X.M.; Yuan, H.L.; Hattendorf, B.; Günther, D.; Chen, L.; Hu, S.H. Determination of forty two major and trace elements in USGS and NIST SRM glasses by laser ablation-inductively coupled Plasma-Mass spectrometry. Geostand. Newsl. 2002, 26, 181-196. [CrossRef]

121. Hu, Z.C.; Liu, Y.S.; Gao, S.; Xiao, S.Q.; Zhao, L.S.; Günther, D.; Li, M.; Zhang, W.; Zong, K.Q. A “wire” signal smoothing device for laser ablation inductively coupled plasma mass spectrometry analysis. Spectrochim. Acta B 2012, 78, 50-57. [CrossRef]

122. Hu, Z.C.; Liu, Y.S.; Gao, S.; Hu, S.G.; Dietiker, D.; Günther, D. A local aerosol extraction strategy for the determination of the aerosol composition in laser ablation inductively coupled plasma mass spectrometry. J. Anal. At. Spectrom. 2008, 23, 1192-1203. [CrossRef]

123. Hu, Z.C.; Liu, Y.S.; Gao, S.; Liu, W.G.; Zhang, W.; Tong, X.R.; Lin, L.; Zong, K.Q.; Li, M.; Chen, H.H.; et al. Improved in situ Hf isotope ratio analysis of zircon using newly designed $X$ skimmer cone and jet sample cone in combination with the addition of nitrogen by laser ablation multiple collector ICP-MS. J. Anal. At. Spectrom. 2012, 27, 1391-1399. [CrossRef] 
124. Woodhead, J.; Hergt, J.; Shelley, M.; Eggins, S.; Kemp, R. Zircon Hf-isotope analysis with an excimer laser, depth profiling, ablation of complex geometries, and concomitant age estimation. Chem. Geol. 2004, 209, 121-135. [CrossRef]

125. Fisher, C.M.; Vervoort, J.D.; Hanchar, J.M. Guidelines for reporting zircon Hf isotopic data by LA-MC-ICPMS and potential pitfalls in the interpretation of these data. Chem. Geol. 2014, 363, 125-133. [CrossRef]

126. Blichert-Toft, J.; Chauvel, C.; Albarède, F. Separation of Hf and Lu for high-precision isotope analysis of rock samples by magnetic sector-multiple collector ICP-MS. Contrib. Mineral. Petrol. 1997, 127, 248-260. [CrossRef]

127. Harrison, T.M.; Blichert-Toft, J.; Müller, W.; Albarede, F.; Holden, P.; Mojzsis, S.J. Heterogeneous Hadean hafnium: Evidence of continental crust at 4.4 to $4.5 \mathrm{Ga}$. Science 2005, 310, 1947-1950. [CrossRef]

128. Morel, M.L.A.; Nebel, O.; Nebel-Jacobsen, Y.J.; Miller, J.S.; Vroon, P.Z. Hafnium isotope characterization of the GJ-1 zircon reference material by solution and laser ablation MC-ICPMS. Chem. Geol. 2008, 255, 231-235. [CrossRef]

129. Wu, F.Y.; Yang, Y.H.; Xie, L.W.; Yang, J.H.; Xu, P. Hf isotopic compositions of the standard zircons and baddeleyites used in U-Pb geochronology. Chem. Geol. 2006, 234, 105-126. [CrossRef]

130. Sláma, J.; Košler, J.; Condon, D.J.; Crowley, J.L.; Gerdes, A.; Hanchar, J.M.; Horstwood, M.S.; Morris, G.A.; Nasdala, L.; Norberg, N.; et al. Plešovice zircon-A new natural reference material for U-Pb and Hf isotopic microanalysis. Chem. Geol. 2008, 249, 1-35. [CrossRef]

Publisher's Note: MDPI stays neutral with regard to jurisdictional claims in published maps and institutional affiliations.

(C) 2020 by the authors. Licensee MDPI, Basel, Switzerland. This article is an open access article distributed under the terms and conditions of the Creative Commons Attribution (CC BY) license (http://creativecommons.org/licenses/by/4.0/). 